NBER WORKING PAPER SERIES

\title{
MULTINATIONAL PROFIT SHIFTING AND MEASURES THROUGHOUT ECONOMIC ACCOUNTS
}

Jennifer Bruner

Dylan G. Rassier

Kim J. Ruhl

Working Paper 24915

http://www.nber.org/papers/w24915

\author{
NATIONAL BUREAU OF ECONOMIC RESEARCH \\ 1050 Massachusetts Avenue \\ Cambridge, MA 02138 \\ August 2018
}

This paper was prepared for the NBER-CRIW conference on The Challenges of Globalization in the Measurement of National Accounts. For comments and helpful questions, we thank Ray Mataloni, Brent Moulton, Marshall Reinsdorf, Peter van de Ven, Dan Yorgason and especially our discussant Steve Redding. The statistical analysis of firm-level data on U.S. multinational companies and companies engaged in international transactions was conducted at the Bureau of Economic Analysis, U.S. Department of Commerce, under arrangements that maintain legal confidentiality requirements. The views expressed in this paper are solely those of the authors and not necessarily those of the U.S. Department of Commerce or the Bureau of Economic Analysis or the National Bureau of Economic Research.

NBER working papers are circulated for discussion and comment purposes. They have not been peer-reviewed or been subject to the review by the NBER Board of Directors that accompanies official NBER publications.

(C) 2018 by Jennifer Bruner, Dylan G. Rassier, and Kim J. Ruhl. All rights reserved. Short sections of text, not to exceed two paragraphs, may be quoted without explicit permission provided that full credit, including $\odot$ notice, is given to the source. 
Multinational Profit Shifting and Measures throughout Economic Accounts

Jennifer Bruner, Dylan G. Rassier, and Kim J. Ruhl

NBER Working Paper No. 24915

August 2018

JEL No. E01,F23,F60,H26

\section{ABSTRACT}

Profit shifting to low-tax countries imposes challenges for the treatment of multinational enterprises in economic accounts. Using adjustments for profit shifting calculated in Guvenen et al. (2017) under an alternative measurement methodology, this paper empirically demonstrates how the effects of profit shifting cascade throughout a fully articulated set of economic accounts for the United States in 2014. We find a 1.5 percent and 3.5 percent increase in measured U.S. gross domestic product and operating surplus, respectively, and a 33.5 percent decrease in measured income receivable from the rest of world. As a result of offsetting effects, measured U.S. gross national saving decreases by 0.8 percent, and national borrowing increases by 6.9 percent. There are also potentially significant implications for analytic uses of the measures, including decreases for the labor share of income and the return on U.S. direct investment abroad and increases for the trade in services balance and the return on domestic non-financial business.

Jennifer Bruner

Bureau of Economic Analysis

4600 Silver Hill Road

Washington, DC 20233

Jennifer.Bruner@bea.gov

Dylan G. Rassier

Bureau of Economic Analysis

4600 Silver Hill Road

Washington, DC 20233

dylan.rassier@bea.gov
Kim J. Ruhl

Department of Economics

University of Wisconsin-Madison

7444 Social Science Building

1180 Observatory Drive

Madison, WI 53706

and NBER

ruhl2@wisc.edu 


\section{Introduction}

Economic accounts offer a comprehensive summary of stocks and flows for a given economy. To promote consistency and comparability of economic accounting measures across economies and time, economic accounts are based on internationally agreed principles that reflect organizing conventions from business accounting and definitions and concepts from economic theory. The primary sources of guidance on economic accounts are the System of National Accounts (SNA) (European Commission et al., 2009) and the Balance of Payments and International Investment Position Manual (BPM) (International Monetary Fund, 2009). The SNA framework is designed with a set of inter-related balanced accounts for five domestic institutional sectors and an additional account for transactions and positions with the rest of world. The BPM framework is also designed with a set of inter-related balanced accounts that provide more detail on the SNA rest of world account. The SNA and BPM frameworks are intentionally harmonized to ensure a consistent treatment of rest of world transactions, other flows, and positions in each framework.

Under SNA and BPM recommendations, rest of world transactions are attributable to economies based on the residences of transacting entities. Under this treatment, affiliates within multinational enterprises (MNEs) are considered resident in the economies in which they are located. While the residence of an entity is generally the economy in which the entity is physically located, an entity with few or no attributes of physical presence - such as a holding company or a special purpose entity - is considered resident in its economy of legal incorporation or registration. In this case, the entity is not consolidated with its parent unless the entity is resident in the same economy as its parent. As a result, economic accounts for a given economy reflect transactions, other flows, and positions that are recorded in each resident entity’s separate accounting recordsknown as the method of separate accounting.

A trend in the last couple of decades is MNEs that are structured with holding companies or special purpose entities that are created for purposes other than production. In particular, MNEs have access to countries that vary widely in corporate tax rates, which enables profit-maximizing MNEs to legally take advantage of differences in national tax regimes and shift profits from high tax countries to low tax countries through transfer pricing and complex global structuring that generally includes holding companies or special purposes entities. Sanchirico (2015) describes these strategies as “unsoundably elaborate and only rarely publicly visible” (page 210), and they 
have generated concern among official statistics compilers and users of official statistics regarding the SNA and BPM treatment of transactions within MNEs and their effects on economic accounting measures. ${ }^{1}$

In the U.S. economic accounts, the treatment of transactions within MNEs under the residence concept is generally consistent with SNA and BPM recommendations. As a result, Guvenen, Mataloni, Rassier, and Ruhl (2017) study offshore profit shifting within MNEs as a source of the measured slowdown in U.S. productivity growth. ${ }^{2}$ Under the international guidelines, profits shifted out of the U.S. may generate low measures of domestic real value-added growth in official statistics, yielding a slowdown in related measured productivity growth. In contrast to the method of separate accounting, the authors construct an adjusted time series of business sector real value-added that is based on a measurement methodology known as formulary apportionment. Under formulary apportionment, the total worldwide earnings of MNEs are attributed to locations based on apportionment factors such as compensation and sales that aim to capture the true location of economic activity. Since earnings by U.S. MNEs are disproportionately booked to low tax jurisdictions in which little real economic activity occurs, the result is a net reattribution of earnings on U.S. direct investment abroad (USDIA) from taxadvantaged locations to U.S. parents. Holding prices constant, the reattribution generates an implied increase in measured domestic business sector real value-added and related measured labor productivity growth. ${ }^{3}$

In this paper, we use the same adjustments of profit shifting by U.S. MNEs calculated in Guvenen et al. (2017) for value-added in the production account to empirically demonstrate how “offshore profit shifting” - profit shifting accomplished through rest of world transactions - affects other key economic accounting measures throughout the SNA and BPM frameworks for the United States in 2014. We limit the scope of adjustments to U.S. MNEs because complete data are not available for foreign MNEs operating in the United States. Consistent with Guvenen et al. (2017),

\footnotetext{
${ }^{1}$ See, for example, Lipsey (2010), Rassier (2017), and United Nations et al. (2011).

2 Other studies that consider possible measurement explanations for the recent productivity slowdown include Brynjolfsson and McAfee (2011), Byrne, Fernald, and Reinsdorf (2016), Byrne, Oliner and Sichel (2015), Mokyr (2014), and Syverson (2017).

${ }^{3}$ Guvenen et al. (2017) do not adjust price indices for any effects that may be caused by transfer pricing. The authors apply their nominal adjustment series to nominal value-added and deflate the adjusted measures of value-added using existing price indices - both aggregate and industry-level indices. Thus, the authors make an implicit assumption that profit shifting made possible by global structuring primarily affects volume measures rather than price measures. If transfer prices are consistent over time or reflect arm's length values, this assumption is reasonable.
} 
we determine offshore profit shifting as the difference between measures derived under formulary apportionment and measures derived under separate accounting. We then apply the aggregate adjustments to relevant published aggregates in each of the SNA and BPM frameworks. We focus on the effects of our adjustments on nominal measures and do not attempt to split the adjustments into volume and price effects. In addition to effects on key economic accounting measures, we present implications for common analytic uses of the U.S. economic accounts, including the labor share of income, national saving rates, returns on domestic non-financial business, returns on foreign direct investment, and external balances.

For 2014, we find notable changes in key economic accounting measures throughout the U.S. economic accounts, which may have significant implications for their analytic uses. Our adjustments yield a 3.5 percent increase in U.S. operating surplus, which generates a 1.5 percent increase in U.S. gross domestic product (GDP) as a result of an implied increase in output that is used as services exports. Likewise, we find a 33.5 percent decrease in U.S. income receivable from the rest of world, which is overwhelmingly attributable to a decrease in earnings on USDIA with a small amount attributable to net interest receivable on USDIA. In dollar amounts, the increase in operating surplus is offset by a larger decrease in income receivable from the rest of world. As a result of these offsetting effects, U.S. gross national income (GNI) and gross national disposable income decrease by 0.1 percent, while gross national saving decreases by 0.8 percent and national borrowing increases by 6.9 percent. Finally, net worth in the balance sheet decreases by 0.3 percent.

The results for analytic uses include a decrease for the labor share of income of 1.4 to 2.4 percentage points because the additional domestic income accrues to capital rather than labor and include a decrease for the return on USDIA of 5.0 percentage points because the adjusted income on USDIA decreases proportionally more than the decrease in the stock of direct investment assets. The results for analytic uses also include an increase for the trade in services balance as a percentage of GDP of 1.4 percentage points because the additional services exports are proportionally higher than the increase in GDP and include an increase for the return on domestic non-financial business of 1.3 percentage points, assuming no change in the stock of produced assets. Changes for the national saving rate and the current account balance as a percentage of GDP are negligible. 
The rest of the paper is organized as follows. The next section describes related tax literature and measurement literature. Section 3 outlines the SNA and BPM frameworks. Section 4 explains our empirical approach and the data. Section 5 presents results and a related discussion. Section 6 summarizes our conclusions.

\section{Related Literature}

Most of the evidence on MNE profit shifting comes from cross-country regressions of MNE profits on tax rates, which generally find a strong relationship between differential tax rates and income attribution. Dharmapala (2014) provides a comprehensive survey of the profit shifting literature. In early work, Hines and Rice (1994) use cross-country regressions to study profit shifting behavior of U.S. MNEs in 1982. They find that U.S. MNEs report high profit rates in tax havens and that the revenue-maximizing tax rate for a typical haven is between 5 and 8 percent. Clausing (2016) uses estimates of the elasticity of MNE income to tax rates to compute the crosscountry distribution of MNE income and determine foregone U.S. tax revenue. She finds that profit shifting amounts to about $\$ 258$ billion in 2012. Dowd et al. (2017) also compute elasticities to determine how MNEs alter the global allocation of profits in response to changes in tax rates. They find that log-linear specifications may understate the sensitivity of profits in low-tax jurisdictions with the opposite effect in high-tax jurisdictions. In addition to these academic studies, country-level indicators of base erosion and profit shifting are offered by the Organization for Economic Cooperation and Development (2015a).

Measurement challenges imposed on economic accountants by MNE profit shifting are widely addressed in the literature. Under separate accounting, profit shifting has been shown empirically to generate questionable outcomes for some published supplemental income-based value-added measures on U.S. MNEs (Lipsey, 2010; Rassier and Koncz-Bruner, 2015). However, no empirical study comprehensively traces the effects of profit shifting throughout the SNA and BPM frameworks. Three papers in United Nations et al. (2011) are dedicated to identifying and explaining challenges associated with allocating production of MNEs and special purpose entities to national economies. In addition, Lipsey (2010) concludes that some U.S. supplemental statistics on financial and operating activities of foreign affiliates of U.S. MNEs are affected by global structuring and the mobility of some factors of production such as intangible assets. Lipsey (2010) suggests, but does not develop, an alternative to separate accounting for measuring transactions in 
services and intellectual property. Early work by Baldwin and Kimura (1998) and Kimura and Baldwin (1998) also suggests supplemental concepts for organizing foreign direct investment and trade statistics based on ownership. Landefeld et al. (1993) evaluate ownership-based trade measures and propose an alternative residence-based trade measure.

Formulary apportionment has been primarily applied in multijurisdictional tax practice. The treatment of global income under formulary apportionment is explored in multidisciplinary research (Gordon and Wilson, 1986; Clausing and Avi-Yonah, 2007), and formulary apportionment has been proposed as an alternative to the complexity and subjectivity of transfer pricing for the allocation of international tax obligations within multinationals in studies such as Avi-Yonah (2010) and Fuest, Hemmelgam, and Ramb (2007). However, formulary apportionment also presents challenges from a tax policy perspective, which is demonstrated in Altshuler and Grubert (2010) and Hines (2010). Because firm-level data collected on statistical surveys may only be used for statistical purposes and not for the purpose of taxation or regulation, formulary apportionment applied in economic accounting faces fewer challenges compared to its use in international taxation.

\section{Accounting Frameworks}

Offshore profit shifting imposes two challenges for the treatment of MNEs in the SNA and $B P M$ frameworks. First, transactions within MNEs are valued using transfer pricing methods that may fail to resemble market outcomes, which is the preferred basis for all transactions recognized in the SNA and BPM. Second, MNEs are structured with holding companies and special purpose entities that may not engage in actual production because such structuring simply facilitates the strategic location of intangible productive assets and related income as well as the artificial characterization of financial claims and liabilities.

One common arrangement among MNEs is a series of sublicensing transactions on intellectual property that results when the intellectual property is legally owned, in whole or in part, by a holding company in a low-tax jurisdiction. In economic accounts, these arrangements can affect production and related income measures such as GDP and operating surplus because legal ownership of intellectual property is often used as a practical solution to determine economic ownership. Another common arrangement is the characterization of a financial instrument as debt in one jurisdiction and as equity in another jurisdiction to take advantage of differences in 
taxability of interest and dividend flows. In this case, economic accounting measures such as GNI can be affected as a result of interest and dividend flows. The consequences of these and similar arrangements is a wedge between the location of production, the location of underlying factors of production, and the location of means for financing production, which affects the interpretability of key economic accounting measures in the SNA and BPM frameworks.

\subsection{Overview of the SNA and BPM Frameworks}

The SNA framework is divided into five domestic institutional sectors that include financial corporations, non-financial corporations, general government, households, and non-profit institutions serving households. For each sector, the SNA groups accounts according to whether they include current transactions or transactions and flows in the accumulation of assets and liabilities. The "current accounts" include a production account and multiple income accounts that reflect the generation, distribution, redistribution, and use of income. The "accumulation accounts” include a capital account that records transactions in non-financial assets and a financial account that records transactions in financial assets and liabilities. The accumulation accounts also include accounts for other changes in assets and liabilities that are not a result of transactions. In addition to the current accounts and the accumulation accounts, the SNA framework includes a balance sheet that records opening and closing stocks as well as changes between them for nonfinancial assets, financial assets, liabilities, and resulting net worth.

The balanced structure of the SNA is made possible by the inclusion of a goods and services account and by balancing items or residuals in each account. The goods and services account supports the fundamental accounting identity that the supply of goods and services from domestic output and imports must equal the uses of goods and services for intermediate consumption, final consumption, capital formation, and exports. The balancing items link one account to the next in a sequence of accounts that includes the production account, income accounts, capital account, and financial account. The SNA balancing items are generally considered key measures in the SNA framework because they help guide macroeconomic policy-they include items such as valueadded, operating surplus, national income, disposable income, saving, net lending/borrowing, and net worth.

In addition to the five domestic institutional sectors, the SNA framework includes a set of

accounts for transactions and positions with the rest of world, which are also included with more detail in the $B P M$ framework. Like the SNA framework, the $B P M$ framework is a sequence of 
accounts with balancing items or residuals. In addition, concepts and definitions are intentionally harmonized between the SNA and BPM. There are, however, two notable differences in scope and two notable organizational differences between the two frameworks.

One difference in scope is that the SNA framework includes three core accounts that are not necessary in the BPM framework: production account, generation of income account, and use of income account. The second difference in scope is that every transaction in the SNA framework is recorded from the perspective of each institutional sector to the transaction, which requires a quadruple entry accounting system with a debit and a credit for each sector. As a result, rest of world transactions in the SNA framework are recorded from the perspective of the rest of world. In contrast, each transaction in the BPM framework is recorded only from the perspective of resident institutional sectors, which allows for a more traditional double entry accounting system.

One organizational difference is that the BPM groups accounts according to whether they contribute to the balance of payments or the international investment position. The "balance of payments" consists of a current account, a capital account, and a financial account. The current account in the balance of payments includes a goods and services account and two income accounts. Entries in the current account generally capture current transactions, which is akin to the current accounts of the SNA. The "international investment position" records beginning and ending positions as well as changes between them for financial assets (i.e., claims of residents on non-residents or reserves) and liabilities (i.e., claims of non-residents on residents), which is akin to the balance sheet of the SNA. Changes between beginning and ending positions are attributable to financial account transactions and other changes in financial assets and liabilities that are not a result of transactions.

The second organizational difference between the SNA and BPM frameworks is classification of financial assets and liabilities. The SNA classifies financial assets and liabilities by type of instrument (e.g., currency, debt, equity, etc.). In addition to instrument classification, the $B P M$ classifies financial assets and liabilities by functional category (e.g., direct investment, portfolio investment, reserve assets, etc.). Transactions among MNE parents and affiliates are included in the direct investment category.

Like balancing items in the SNA framework, balancing items in the BPM framework are generally considered key measures because they have implications for macroeconomic policythey include items such as the balance on goods and services, the current account balance, net 
lending/borrowing, and the net international investment position. Figure 1 provides an overview of the SNA and BPM frameworks.

\subsection{Institutional Units and Residence}

The most basic unit of observation in the SNA and BPM is an institutional unit, which satisfies four criteria including the right to own assets and incur liabilities, the ability to make economic decisions and to be held legally accountable for the decisions, and the existence of a complete set of financial accounting records for the unit (or the feasibility of compiling a complete set). The SNA and BPM attribute stocks of assets and liabilities and related flows to an economy based on the residence of the institutional unit. Residence is the economic territory in which an institutional unit has a center of predominant economic interest, which is generally defined in the $S N A$ and $B P M$ as a physical location from which the unit engages in economic activity and transactions. An economic territory in the SNA and BPM is defined as the legal jurisdiction to which an institutional unit is subject. The SNA and BPM concepts of economic territory and residence are designed to attribute the stocks and flows of an institutional unit based on residence in a single economic territory, including stocks and flows within MNEs.

In the case of an MNE structured with a holding company or a special purpose entity that lacks physical presence, residence for the holding company or special purpose entity is determined in the SNA and BPM as the economic territory under whose legal jurisdiction the unit is incorporated or registered. If the unit is legally located in the same economy as its parent, the unit is consolidated with the parent and not recognized as a separate institutional unit because it does not satisfy the four SNA and BPM criteria for an institutional unit. However, if the unit is legally located in an economy different from its parent, the unit is recognized as a separate institutional unit. As a result, the SNA and BPM frameworks include stocks and flows within MNEs regardless of any physical economic activity.

The SNA and BPM recommendations to recognize an institutional unit based on legal registration or incorporation of holding companies and special purpose entities introduces an exception to the recommendation for determining residence based on predominant economic interest. The recommendation raises concerns for effects on "real" economic accounting measures such as GDP and GNI since holding companies and special purpose entities are used by MNEs for transactions in intellectual property and other services. However, the recommendation is important to users of economic accounts such as central banks and other institutions responsible 
for supervising financial markets since holding companies and special purpose entities are also used by MNEs to facilitate financing arrangements and to channel funds in a way that can expose MNEs and compiling economies to global financial risks.

\subsection{Accounting Identities and Relationships}

Based on the formulary methodology that we outline in section 4, we will be making adjustments to three measures: operating surplus, earnings on USDIA, and net interest receivable on USDIA. Before we make our adjustments, we first outline the relationships among the measures. We focus on production and primary income measures because we do not make adjustments to secondary income measures or measures of capital formation.

The most fundamental accounting identity in the SNA framework is the supply-use identity, which is embodied in the goods and services account. The intuition of the supply-use identity is that the total amount of goods and services available for use in an economy for a given period must be supplied by either domestic output $(Q)$ or imports $(M)$. The uses of goods and services include intermediate consumption $(Z)$, final consumption $(C)$, capital formation $(I)$, and exports $(X)$. The following equation summarizes the supply-use identity:

$$
Q+M=Z+C+I+X .
$$

If we rearrange equation (1) as follows, the result yields two familiar approaches to measuring GDP:

$$
Q-Z=C+I+X-M .
$$

The left side of equation (2) yields the production approach and the right side yields the expenditure approach—both government expenditures and private expenditures are included in $C$ and $I$.

An additional approach to measuring GDP is the income approach, which is a matter of summing the incomes generated through production. Incomes generated through production include compensation of employees $(W)$, taxes $(T)$ less subsidies $(S)$ on production and imports, and operating surplus $(O) .{ }^{4}$ Each of the approaches to GDP can be summarized as follows:

$$
G D P=\underbrace{Q-Z}_{\text {Production Approach }}=\underbrace{C+I+X-M}_{\text {Expenditure Approach }}=\underbrace{W+T-S+O}_{\text {Income Approach }} .
$$

\footnotetext{
${ }^{4}$ Operating surplus may either be measured as a residual or measured directly in which case the primary components include entrepreneurial income of enterprises and rental income on owner-occupied housing.
} 
In the SNA sequence of accounts, the production account reflects the production approach to measuring GDP. In addition, the generation of income account reflects the income approach and the goods and services account reflects the expenditure approach.

\section{Operating Surplus}

In the SNA framework, operating surplus is a domestic measure-i.e., it is not calculated in the rest of world account and it is not included in the BPM framework. To better understand operating surplus, we start with a simplified version of net income $(\pi)$ for a domestic firm (either MNE or non-MNE), which is the difference between total income and total expenditures. ${ }^{5}$ Total income includes sales of output $(q)$, holding gains $(h)$, earnings on equity $(d)$, and interest receivable $\left(i_{r}\right){ }^{6} \quad$ Total expenditures include intermediate inputs $(z)$, payments for labor $(w)$, income taxes payable $(t)$, and interest payable $\left(i_{p}\right)$. Net income for the firm can be written as follows:

$$
\pi=\underbrace{\left(q+h+d+i_{r}\right)}_{\text {Total Income }}-\underbrace{\left(z+w+t+i_{p}\right)}_{\text {Total Expenditures }} .
$$

Note that earnings on equity and interest flows may include transactions with directly held foreign affiliates when the domestic firm is an MNE.

To derive a measure of operating surplus, equation (4) is adjusted to exclude all components that do not result directly from current production, including holding gains, earnings on equity, interest receivable, income taxes payable, and interest payable. The result is as follows:

$$
\text { Operating Surplus }=q-z-w \text {. }
$$

The first two terms in equation (5) (i.e., $q$ minus $z$ ) reflect a measure of value-added, and the last term (i.e., $w$ ) is a measure of compensation, which reflects labor's contribution to value-added. Thus, operating surplus is invariant to all flows that do not result directly from current production. ${ }^{7}$

\footnotetext{
${ }^{5}$ In this simplified version, we ignore taxes and subsidies on production and imports, economic depreciation on property, plant and equipment, rents on natural resources, and other income and expenditures, such as transfers, that are not explicitly included. We also assume the domestic firm has no indirect holdings in foreign affiliates.

${ }^{6}$ For economic accounting purposes, the scope of sales $(q)$ may include explicit sales of products to customers or may include implicit sales of output such as own-account software.

${ }^{7}$ Operating surplus is measured for all institutional sectors except the rest of world in the SNA framework. In contrast, entrepreneurial income is only measured for the non-financial and financial corporations sectors. To derive a measure of entrepreneurial income, operating surplus in equation (5) is adjusted to include earnings on equity, interest receivable, and interest payable. Thus, entrepreneurial income is only invariant to holding gains and income taxes payable. We do not articulate a measure of entrepreneurial income separate from operating surplus in this paper because we present all sectors as one total economy.
} 


\section{$\underline{\text { Income on Foreign Direct Investment }}$}

In the SNA and BPM frameworks, foreign direct investment by a domestic firm is treated as a financial asset, and income on foreign direct investment reflects a return on that asset. Income on foreign direct investment includes two components: earnings and net interest receivable. Earnings on foreign direct investment include the domestic firm's share of a foreign affiliate's earnings, whether distributed or reinvested. Since they reflect a return on a financial asset, earnings on foreign direct investment are derived by adjusting net income from equation (4) for the foreign affiliate to exclude holding gains only. ${ }^{8}$ The calculation of earnings on direct investment in a wholly-owned foreign affiliate $(f)$ is as follows: ${ }^{9}$

$$
\text { Earnings on FDI }=q^{f}-z^{f}-w^{f}+d^{f}+i_{r}^{f}-i_{p}^{f}-t^{f} \text {. }
$$

Foreign income taxes payable directly by the foreign affiliate are included in equation (6) because they reduce the domestic firm’s return.

Net interest receivable on foreign direct investment includes interest receivable by the domestic firm from the foreign affiliate less interest payable by the domestic firm to the foreign affiliate. Net interest receivable by the domestic firm from the foreign affiliate is exactly equal to net interest payable by the foreign affiliate to the domestic firm, which if all interest flows in equation (6) are between the domestic firm and the foreign affiliate, can be calculated as follows:

Net Interest Receivable on FDI $=i_{p}^{f}-i_{r}^{f}$.

Adding equations (6) and (7) yields the following equation for income on foreign direct investment:

$$
\text { Income on FDI }=q^{f}-z^{f}-w^{f}+d^{f}-t^{f} .
$$

Note that equation (6) can be subtracted from equation (8) to obtain a measure of net interest receivable on foreign direct investment as shown in equation (7) - this is the approach we take in computing the adjustment for net interest receivable. Since equation (7) assumes that all interest flows are between the domestic firm and the foreign affiliate, equation (8) includes no interest flows. However, interest flows may likely exist between the foreign affiliate and unrelated firms.

\footnotetext{
${ }^{8}$ Since holding gains reflect changes in prices rather than production, they are not included in SNA and BPM measures of income. They are instead reflected in the SNA and BPM revaluation accounts, which contribute to changes in net worth and the international investment position.

${ }^{9}$ For a majority-owned foreign affiliate that is not 100 percent owned, equation (6) would need to include the parent firm's ownership share in the foreign affiliate.
} 
Intuitively, income on foreign direct investment reflects "actual" income after the elimination of intrafirm interest flows, and earnings on foreign direct investment reflects amounts booked to each part of the firm. Measures comparable to equations (6) and (8) for the foreign affiliate can also be calculated for the domestic firm in order to generate consolidated measures of earnings and income for the entire MNE.

\section{Gross National Income}

The difference between GDP and GNI in the SNA framework is income receivable from and payable to the rest of world, which can be summarized as follows:

$$
G N I=G D P+\text { Income Receivable from RoW - Income Payable to RoW }{ }^{10}
$$

Income receivable from and payable to the rest of world includes income on foreign direct investment, income on portfolio investment, income on other investment, and income on reserve assets. Offshore profit shifting may affect each of the right-side components of equation (9). However, we only calculate adjustments for GDP and income receivable from the rest of world due to limited data on foreign MNEs that would be required to adjust income payable to rest of world.

\section{Empirical Approach and Data}

Our objective is to demonstrate the effects of offshore profit shifting on key U.S. economic accounting measures that are compiled under a method of separate accounting. As explained in section 3, profit shifting within MNEs is generally accomplished under separate accounting through transfer pricing and global structuring that includes the use of holding companies or special purpose entities with very little physical presence and very little economic activity. While the identification of a typical institutional unit under the SNA and BPM recommendations depends on the four criteria that generally reflect economic substance, the SNA and BPM make an exception for holding companies and special purpose entities that are located in economies other than their parents or other affiliated entities. As a result, key measures throughout the SNA and BPM frameworks may not adequately capture the economic activity of some MNE entities. Thus, we follow Guvenen et al. (2017) and design an empirical framework to attribute economic accounting

\footnotetext{
${ }^{10} \mathrm{GNI}$ is an SNA term for income earned by domestic-owned factors of production anywhere in the world. In the U.S., the equivalent of GNI is gross national product (GNP), which is derived from expenditure-based GDP by adding income receivable from the rest of world and subtracting income payable to the rest of world.
} 
measures based on physical presence and other attributes of economic activity within MNEs. In particular, we use formulary apportionment to reattribute operating surplus, earnings, and net interest received by U.S. parents from their foreign affiliates.

Formulary apportionment attributes measures to locations based on apportionment factors intended to reflect economic activity of each entity in an MNE-the essence of the SNA and BPM concepts of institutional unit and residence. For our apportionment factors, we use compensation and sales to unaffiliated parties. Compensation reflects labor's contribution to production. In contrast to employment, which only captures number of employees, compensation captures variation in returns to labor across entities located in different countries and industries, assuming workers are paid their marginal products. Likewise, the market presence of each entity is captured by the sales measure, and restricting sales to unaffiliated parties mitigates problems with transfer pricing and global structuring. Under each factor, formulary apportionment allocates less economic activity (e.g., operating surplus) to locations with low-paid workers and low market presence than to locations with high-paid workers and high market presence. ${ }^{11}$

In addition to the conceptual basis of our chosen apportionment factors, there are two practical considerations that support formulary apportionment as a reasonable alternative to separate accounting. First, formulary apportionment is suggested in the SNA as a potential alternative to allocate the market value of global firms in the balance sheet. As a result, formulary apportionment should also be a reasonable potential alternative to allocate production and income measures. Second, in contrast to the opacity of separate accounting under complex global structuring, formulary apportionment promotes transparency because it is easy to understand and easy to apply if appropriate data are available.

In lieu of formulary apportionment, another option for allocating measures on holding companies and special purpose entities is a treatment that either consolidates them entirely with their parents or considers them supranational entities with no location as suggested for intellectual property products in Moulton and Van de Ven (2018). If the apportionment factors for a holding company or special purpose entity reflect no economic activity (e.g., no compensation and no unaffiliated sales), then formulary apportionment allocates measures away entirely from the

\footnotetext{
${ }^{11}$ Under country-by-country reporting, the Organization for Economic Cooperating and Development (2015b) asserts that indicators such as profits, income taxes paid, revenue, number of employees, and tangible assets of individual MNE entities should help tax administrations determine the location of economic activity and evaluate the presence of audit risk.
} 
holding company or special purpose entity and toward other entities within the firm where economic activity is evident. The measures are split between the parent and other entities based on their own proportionate shares of economic activity reflected in the apportionment factors. As a result, formulary apportionment strikes a balance between the current treatment of holding companies and special purpose entities as completely separate institutional units and a treatment that either consolidates them entirely with their parents or considers them supranational entities with no location.

Despite the strengths associated with formulary apportionment as a measurement tool, note that we are not proposing formulary apportionment as a replacement for separate accounting in the SNA and BPM but rather using it to generate a point of reference to estimate the effects of profit shifting under a method of separate accounting.

\subsection{Formulary Apportionment}

Consider an MNE $(m)$ that is composed of one domestic parent and at least one foreign affiliate. Let $\psi$ denote operating surplus, earnings, or income determined under a method of separate accounting for each entity ( $n$ ) (i.e., parent and foreign affiliates). Following Guvenen et al. (2017), we construct for each entity in the MNE an apportionment weight $\left(\omega_{n}\right)$ that reflects the entity's share of the total apportionment factors. Weighting unaffiliated sales and compensation equally yields the following apportionment weights for each entity within the MNE:

$$
\omega_{n}=\underbrace{\left(\frac{1}{2} \times \frac{w_{i} l_{i}}{\sum_{i} w_{i} l_{i}}\right)}_{\text {Compensation }}+\underbrace{\left(\frac{1}{2} \times \frac{p_{i} y_{i}}{\sum_{i} p_{i} y_{i}}\right)}_{\text {Unaffiliated Sales }} \quad \forall n \in m . .^{12}
$$

Under formulary apportionment, measured operating surplus, earnings, or income $(\bar{\psi})$ attributable to each entity $n$ within MNE $m$ is calculated as follows:

$$
\bar{\psi}_{n}=\omega_{n} \sum_{i} \psi_{i} \quad \forall n \in m .
$$

The measure attributable to each entity under formulary apportionment is a weighted average of the consolidated measure determined for the MNE (i.e., parent and foreign affiliates) under separate accounting. Thus, measured operating surplus, earnings, or income attributable to each

\footnotetext{
${ }^{12}$ Results will be affected by the chosen apportionment factors, and papers such as Runkel and Schjelderup (2011) contribute to a body of literature that focuses solely on the choice of apportionment factors. Guvenen et al. (2017) present alternative results under different weights on the apportionment factors - weighting compensation 100 percent and unaffiliated sales 100 percent in separate calculations - and find that their results are robust to the alternative weighting schemes. They ultimately settle on a simple average for their core results.
} 
entity is proportionate to the entity's economic activity embodied by the chosen apportionment factors.

The formulary adjustment for each entity is calculated by subtracting the measure determined under separate accounting from the measure determined under formulary apportionment as follows:

$$
\varepsilon_{n}=\bar{\psi}_{n}-\psi_{n} \quad \forall n \in m \text {. }
$$

The formulary adjustment for each entity reflects an amount of operating surplus, earnings, or income to be added to or subtracted from each entity, depending on whether the adjustment is positive or negative. The aggregate formulary adjustment for U.S. parents is exactly equal (with an opposite sign) to the aggregate formulary adjustment for their foreign affiliates.

\subsection{Data}

We use unpublished firm-level survey data collected by the Bureau of Economic Analysis (BEA) on the financial and operating activities of U.S. MNEs - referred to as the activities of multinational enterprise (AMNE) data - and on the direct investment income transactions of U.S. MNEs for 2014. ${ }^{13}$ The AMNE data cover the worldwide operations of U.S. MNEs and contain balance sheet information and income statement information for U.S. parents and their foreign affiliates. For each U.S. parent and foreign affiliate, the data include information on net income and the components of total income and total expenditures consistent with equation (4) under separate accounting. In addition, the data include compensation and unaffiliated sales for each U.S. parent and foreign affiliate necessary for the apportionment weights in equation (10). Moreover, the AMNE data include information necessary to construct measures of operating surplus, earnings, and income equivalent to equations (5), (6), and (8) for each U.S. parent and foreign affiliate. The direct investment income transactions data include data on earnings of foreign affiliates and interest flows between U.S. parents and foreign affiliates. ${ }^{14}$

In addition to the firm-level survey data, we use published data for 2014 from the U.S. National Income and Product Accounts (NIPAs), the U.S. Industry Economic Accounts (IEAs),

\footnotetext{
13 The financial and operating data are reported on the Benchmark Survey of U.S. Direct Investment Abroad (form BE-10) for all U.S. parents and all foreign affiliates. The income transactions data are reported on the Quarterly Survey of U.S. Direct Investment Abroad Direct Transactions of U.S. Reporter with Foreign Affiliates (form BE-577) subject to thresholds for assets, sales, and net income.

14 The income transactions data do not include information on operations that are needed to construct the apportionment factors. Likewise, the data do not include information on U.S. parents. In order to get a complete picture of each U.S. MNE, we use the AMNE data to generate proxies for earnings and income.
} 
the U.S. Integrated Macroeconomic Accounts (IMAs), the U.S. International Transactions Accounts (ITAs), and the U.S. International Investment Position (IIP) accounts. We use the NIPA data and the IEA data to compile the SNA current accounts, and we use the IMA data to compile the SNA accumulation accounts and balance sheets. We use the ITA data to compile the BPM balance of payments, and we use the IIP data to compile the BPM international investment position. ${ }^{15}$

\subsection{Adjustments}

We calculate formulary adjustments as shown in equation (12) using the measures constructed from the BEA survey data - operating surplus, earnings, and income - for each U.S. parent and each foreign affiliate. We then tabulate the formulary adjustments for each measure to derive an aggregate adjustment for domestic operating surplus, earnings on USDIA, and income on USDIA. To derive an aggregate formulary adjustment for net interest receivable on USDIA consistent with equation (7), we subtract the aggregate adjustment for earnings on USDIA from the aggregate adjustment for income on USDIA.

Since the scope of our adjustments is limited to U.S. MNEs due to data limitations, we can rewrite equation (9) to focus exclusively on incomes receivable on USDIA as follows:

$$
G N I=G D P+\text { Earnings on USDIA + Net Interest Receivable on USDIA }+/-\cdots .
$$

The ellipsis in equation (13) denotes all omitted incomes receivable and payable that account for differences between GDP and GNI. We apply our aggregate formulary adjustments constructed with the unpublished survey data to the relevant published aggregates in each of the SNA and BPM frameworks. In particular, we apply our aggregate adjustment for operating surplus to U.S. GDP. Likewise, we apply our aggregate adjustment for earnings on USDIA to the portion of earnings on USDIA that is calculated as reinvested since dividends reflect an actual payment. Finally, we apply our aggregate adjustment for net interest receivable on USDIA to the interest portion of income on USDIA.

\footnotetext{
${ }^{15}$ In practice, there are statistical discrepancies between key measures for the U.S. - such as net lending/borrowing and trade balances - in the NIPAs, IMAs, ITAs, and IIP as a result of different source data and measurement methodologies. We do not attempt to reconcile the discrepancies but rather use data as published in each of the accounts.
} 


\section{Results}

Our formulary adjustment for operating surplus in equation (5) amounts to a $\$ 255.5$ billion increase in U.S. operating surplus in 2014, which implies that level of value-added attributable to foreign affiliates of U.S. MNEs under a method of separate accounting is instead attributable to U.S. parents under a method of formulary apportionment. Likewise, our adjustment for earnings on USDIA in equation (6) amounts to a \$273.1 billion decrease in earnings on USDIA, which reflects earnings attributable to foreign operations of U.S.-owned firms under separate accounting that are no longer attributable under formulary apportionment because they are accrued domestically. In addition, the adjustment for net interest receivable on USDIA amounts to an \$8.7 billion decrease, which is the difference between the adjustment for income on USDIA of \$281.8 billion calculated with equation (8) and the adjustment for earnings on USDIA of \$273.1 billion. The adjustment for net interest suggests that financing arrangements between U.S. parents and foreign affiliates also raise the measure of income on USDIA under the SNA and BPM recommendations for separate accounting. For each of the adjustments, about 75 percent of the adjustment is attributable to foreign affiliates classified as holding companies, which is consistent with profit shifting accomplished through the use of holding companies and special purpose entities.

We present three sets of adjusted and unadjusted (i.e., published) measures. The first set (tables 1.1 to 1.2 and 2.1 to 2.2) shows adjusted and unadjusted measures for the U.S. in the BPM framework. The second set (tables 3.1 to 3.3) shows adjusted and unadjusted measures for the U.S. in the SNA framework. The SNA and BPM sets of results demonstrate the effects of offshore profit shifting on the key measures in each framework. The initial entries for our adjustments are outlined in boxes in our presentation of the SNA and BPM accounts. In addition, the adjustments are shown separately by type: operating surplus, earnings on USDIA, and net interest received on USDIA. ${ }^{16}$ The third set of results includes figures to demonstrate implications for five common

\footnotetext{
${ }^{16}$ Although the standard presentation of BEA statistics on direct investment transactions, positions, and associated income is on an asset-liability basis in accordance with international guidelines, we use a directional basis in tables 1.1 to 1.2 and 3.1 to 3.3. For our purposes, the directional basis is more analytically useful, and it is consistent with the recording of direct investment in the U.S. IMAs. For equity, there is no difference between a directional basis and an asset-liability basis. However, there is a difference for debt. Measures of direct investment transactions and earnings are shown with current cost adjustment in tables 1.1 to 1.2 and 3.1 to 3.3. Direct investment positions are shown at market value in tables 2.1 to 2.2. We provide a reconciliation of the direct investment position on a directional basis with current cost adjustment and the direct investment position on an asset-liability basis at market value in appendix table A1.
} 
analytic uses of the U.S. economic accounts: labor share of income, national saving rates, returns on domestic non-financial business, returns on foreign direct investment, and external balances.

\subsection{BPM Measures}

The $B P M$ balance of payments is presented in table 1.1. In the goods and services account, we apply the $\$ 255.5$ billion adjustment for operating surplus as an implied increase in charges for the use of intellectual property (row 14) by foreign affiliates. The increase in measured exports of goods and services is 10.8 percent, which is a result of the increase in U.S. exports of services with no change for trade in goods.

The treatment of the adjustment as charges for the use of intellectual property is consistent with a simple model outlined in Guvenen et al. (2017) that attributes profit shifting made possible by the mobility of intangible capital. Likewise, the treatment is consistent with literature that focuses on intangible capital as an explanation for higher rates of return earned by U.S. MNEs on their direct investments abroad compared with rates of return earned by foreign MNEs on their direct investments in the U.S. (McGrattan and Prescott, 2010; Bridgman, 2014). Intangible capital may result from research and development $(\mathrm{R} \& D)$ efforts, which are generally embodied in observable measures such as patents or formulas in addition to a firm's profits. Intangible capital may also result from efforts other than R\&D such as brand and trademark development, management consulting, and workforce training, which are generally less observable but still reflected in the firm's profits. Corrado, Hulten, and Sichel (2009) refer to the latter form of intangible capital as "economic competencies" and subsequent authors have referred to it as “organization capital” (e.g., Eisfeldt and Papanikolaou, 2013). We consider transactions (explicit and implicit) in both forms of intangible capital to be candidates for charges for the use of intellectual property.

In the primary income account in table 1.1, we apply the $\$ 273.1$ billion adjustment for earnings on USDIA as a decrease in reinvested earnings (row 25). Likewise, we apply the \$8.7 billion adjustment for net interest received on USDIA as a decrease in interest flows (row 26), which we consider a change in the price of intrafirm lending (i.e., arm’s length interest rates) rather than a change in the underlying stocks of intrafirm debt. ${ }^{17}$ In addition, the adjustment for net

\footnotetext{
17 This treatment means we do not adjust the underlying stocks of intrafirm debt. In reality, the result may suggest changes in both the price of intrafirm lending and stocks of intrafirm debt. In either case, the result is counterintuitive if firms engage in intrafirm financing arrangements to shift profits-a practice known as earnings stripping. In a report to Congress, the U.S. Treasury Department (2007) concludes that U.S. MNEs are less inclined to engage in
} 
interest implies either a decrease in interest received by U.S. parents from their foreign affiliates or an increase in interest paid by U.S. parents to their foreign affiliates. ${ }^{18}$ The decrease in measured income receivable from non-residents is 34.9 percent. We do not calculate any measured effects in the secondary income account.

The positive effects of the operating surplus adjustment in the goods and services account are more than offset by the larger negative adjustments for earnings and net interest received on USDIA in the primary income account. Thus, the net effect on the current account balance (row 1) in table 1.1 is a $\$ 26.4$ billion decrease-7.1 percent. Measured U.S. net borrowing (row 35) increases as a result of changes in the preceding accounts. The only change in the financial account in table 1.2 is on measured equity (rows 5 and 6) as a result of the previous adjustment transactions, which also increases net borrowing in the financial account. The increases in measured U.S. net borrowing in both the current and capital accounts and the financial account are 7.1 percent and 8.1 percent, respectively, the difference of which is a result of the statistical discrepancy between the two accounts.

The BPM international investment position for 2014 is presented in table 2.1. Since the international investment position reflects stocks of assets and liabilities, we include accumulations for each of our adjustment measures in the financial account for 1973-2014 using annual estimates from Guvenen et al. (2017). The cumulative adjustments for operating surplus, earnings on USDIA, and net interest received on USDIA (row 3) from the financial account are \$3.457 trillion, $\$ 3.587$ trillion, and $\$ 145.4$ billion, respectively. The decrease in measured international investment position assets is 1.1 percent because the increases in services exports are less than the decreases in reinvested earnings and net interest receivable on USDIA over time. Thus, the decrease in the measured net international investment position is 4.0 percent.

earnings stripping than foreign MNEs operating in the U.S. because U.S. firms are subject to anti-deferral rules and passive income rules under U.S. Treasury Regulations that do not apply to foreign firms. BEA's published statistics on direct investment seem to support this conclusion. In 2014, U.S. affiliates' payments of interest to foreign parents were $\$ 30.0$ billion on $\$ 945.8$ billion of debt - an implied interest rate of 3.2 percent - and U.S. affiliates’ interest receipts were $\$ 4.6$ billion on $\$ 384.7$ billion of debt - an implied interest rate of 1.2 percent - which suggests U.S. affiliates incurred a higher interest expense per dollar of debt. In contrast, U.S. parents’ payments of interest to foreign affiliates were $\$ 5.7$ billion on $\$ 528.0$ billion of debt - an implied interest rate of 1.1 percent - and U.S. parents' interest receipts were $\$ 14.7$ billion on $\$ 764.6$ billion of debt - an implied interest rate of 1.9 percent - which suggests U.S. parents incurred lower interest expense per dollar of debt.

18 The $\$ 8.7$ billion decrease reduces net interest received by U.S. parents published for 2014 to almost nothing and could generate a negative net interest received in some years. Since net interest received includes interest received from foreign affiliates less interest paid to foreign affiliates, net interest received can be positive, negative, or zero. 
The BPM beginning and ending direct investment positions for 2014 are presented in table 2.2, which provides further detail on rows 2 to 4 in table 2.1. The difference between the international investment position at the beginning and end of the year results from two sources: financial transactions and other changes. Given the modest size of the net adjustments for financial transactions - a decrease of $\$ 26.4$ billion - we do not make an adjustment for other changes. For the beginning net direct investment position (column 5), the cumulative adjustments decrease the U.S. net direct investment position by 15.4 percent. For the ending net direct investment position (column 8), the cumulative adjustments decrease the U.S. net direct investment position by 27.8 percent because the increases in services exports are less than the decreases in reinvested earnings and net interest receivable on USDIA over time.

\subsection{SNA Measures}

The SNA current accounts are presented in table 3.1. The $\$ 255.5$ billion adjustment for operating surplus in 2014 is a net reattribution of measured operating surplus from foreign affiliates to U.S. parents, which we apply in the production account as an implied increase in output (row 3 ) and in the goods and services account as an implied increase in exports (row 2) to account for the increase in receipts on the use of intellectual property, which was presented in the discussion of the BPM balance of payments in section 5.1. Thus, the supply-use identity is maintained, and the statistical discrepancy is unaffected. The increase in GDP is 1.5 percent, and the percentage increase in operating surplus is 3.5 percent.

The $\$ 273.1$ billion adjustment for earnings on USDIA is also a net reattribution of measured earnings from foreign affiliates to U.S. parents, which we apply in the allocation of primary income account as a decrease in reinvested earnings on foreign direct investment (row 20). Likewise, the $\$ 8.7$ billion adjustment for net interest received on USDIA reflects a reduction in measured net interest received by U.S. parents from their foreign affiliates, which we also apply in the primary income account as a decrease in interest flows (row 18). The decrease in income receivable from the rest of world for both adjustments is 33.5 percent, which is a bit lower than the BPM measures as a result of the difference in the scope of rest of world transactions between the two sets of accounts. ${ }^{19}$

\footnotetext{
${ }^{19}$ In the U.S. NIPAs, U.S. territories, Puerto Rico, and the Northern Mariana Islands are included in the rest of world.
} In the U.S. ITAs, they are treated as part of the United States. 
From an accounting perspective, the adjustment for operating surplus in the production and generation of income accounts may be expected to exactly offset the adjustments for earnings and net interest received on USDIA in the allocation of primary income account. However, the effect of the operating surplus adjustment is more than offset by the effect for earnings and net interest received because of the differences in concepts outlined in section 3.3. Thus, the net effect on measured GNI is a $\$ 26.4$ billion decrease - about 0.1 percent - which we demonstrated is also the change in the current account balance. Absent any related changes in the secondary distribution of income account, the decrease in measured disposable income is also about 0.1 percent. However, measured gross saving in the use of disposable income account decreases by 0.8 percent, and measured net saving decreases by 4.3 percent. The $\$ 26.4$ billion decrease in GNI, disposable income, and saving is a contrast to the increase in operating surplus and GDP. However, the \$26.4 billion decrease is small relative to the effects on operating surplus and income on USDIA. In addition, all adjustments - operating surplus, earnings on USDIA, income on USDIA - are of similar magnitudes.

The SNA accumulation accounts are presented in table 3.2. The only change we include in the capital account is the amount carried forward with the saving measure (row 36) from the use of disposable income account. We do not reallocate capital formation in intellectual property products. ${ }^{20}$ Likewise, the only change we include in the financial account is in equity (row 55) as a result of the previous adjustment transactions - we assume the additional exports that result from the operating surplus adjustment are financed with equity rather than debt. The balancing items in the capital account and the financial account - net lending/borrowing - are also affected by the net decrease of $\$ 26.4$ billion in external transactions. The increase in measured U.S. net borrowing in the capital account is 6.9 percent, and the increase in the financial account is 7.8 percent-the difference between the percentages is a result of the statistical discrepancy between the two

\footnotetext{
${ }^{20}$ We do not make an effort to reallocate flows and stocks of intellectual property products for three reasons. First, the income measures that we reallocate reflect returns to all intangible capital but intellectual property products are only a subset of intangible capital. Second, intellectual property products in the U.S. national accounts are measured as a sum of costs and any reallocation under formulary apportionment would, thus, be reduced by the extent to which costs incurred consist of payments to unrelated parties and to labor. Third, to the extent that intellectual property products consist of R\&D expenditures, very little reallocation would likely result because the majority of R\&D expenditures by U.S. MNEs are incurred by U.S. parents and consist largely of payments to unrelated parties and to labor. Of the $\$ 330.8$ billion spent on R\&D by U.S. MNEs in 2014, $\$ 275.5$ billion - 83.3 percent - was incurred by U.S. parents.
} 
accounts. There are no measured effects in the other changes in the volume of assets account or the revaluation account at the bottom of table 3.2.

The SNA balance sheets are presented in table 3.3. Just like the BPM international investment position, the SNA balance sheets reflect stocks of assets and liabilities, which requires an accumulation of each of our adjustment measures using annual estimates from Guvenen et al. (2017). The opening balance sheet at the top of table 3.3 presents the cumulative adjustments for operating surplus, earnings on USDIA, and net interest received on USDIA for the period 19732013. The closing balance sheet at the bottom of table 3.3 presents the cumulative adjustments for the period 1973-2014. Retaining our assumption that the additional exports that result from the operating surplus adjustment are financed with equity rather than debt, the cumulative adjustments decrease measured U.S. equity assets by $0.5-0.6$ percent for both the opening balance of equity (row 77) and the closing balance of equity (row 102) because the increases in operating surplus are less than the decreases in income receivable from rest of world over time. Thus, measured U.S. net worth in both the opening balance sheet and the closing balance sheet decreases by 0.3 percent.

\subsection{Analytic Uses}

We consider implications for five common analytic uses of the U.S. economic accounts: labor share of income, national saving rates, returns on domestic non-financial business, returns on foreign direct investment, and external balances. We provide additional details on calculations for each of the analytic uses in appendix A.

Karabarbounis and Neiman (2014) and Bridgman (2018) each report declines in the labor share of income since 1975. Following the previous authors, we calculate the labor share for the U.S. corporate business sector by dividing compensation by value-added with and without our operating surplus adjustment for 1975 and 2014. Since compensation in the numerator is unchanged, the results yield declines in the labor share. The shares are reported in figure 2 for three alternative denominators used in Bridgman (2018): gross value-added, net value-added, and net value-added minus taxes less subsidies on production and imports. The adjusted shares reported in figure 2 for 2014 demonstrate a decline of 1.4 percentage points, 1.9 percentage points, and 2.4 percentage points for gross-value-added, net value-added, and net value-added minus taxes less subsidies on production and imports, respectively. In addition, the adjusted shares demonstrate a larger decline in the labor share from 1975 to 2014 under each alternative 
denominator-15.6 percent for gross value-added, 25.5 percent for net value-added, and 28.8 percent for net value-added minus taxes less subsidies on production and imports.

Reinsdorf (2004) presents measures of U.S. personal saving, business saving, and national saving as a percentage of national income. In addition, BEA publishes quarterly and annual measures of net national saving and gross national saving as a percentage of GNI. We present net and gross national saving rates for 2014 in figure 3. We calculate the rates by dividing the national saving measures by GNI, and we apply our formulary adjustments from table 3.1 to both the numerator and the denominator. The rates in figure 3 show relatively small declines of 0.1 and 0.2 percentage point for the net and gross saving measures, respectively, which is a result of the same downward adjustment of $\$ 26.4$ billion that affects both the numerator and the denominator in the calculation.

Osborne and Retus (2017) report rates of return for U.S. domestic non-financial business. The returns are calculated by dividing net operating surplus by the net stock of produced assets for non-financial business. We use the unadjusted rate of return for 2014 directly from Osborne and Retus (2017) and add our formulary adjustments on operating surplus for non-financial industries - an amount of $\$ 217.4$ billion - to the numerator in their calculation to derive an adjusted rate of return for 2014. As we explained in section 5.2, we do not adjust the stock of intellectual property products in the denominator. The result is reported in figure 4, which shows a 1.3 percentage point increase in the rate of return after our adjustments are applied.

McGrattan and Prescott (2010) and Bridgman (2014) document a persistent gap since 1982 between rates of return on direct investment abroad by U.S. MNEs and foreign direct investment in the U.S. (FDIUS) by foreign MNEs. Rates of return are calculated by dividing income on foreign direct investment by the direct investment component of the international investment position. In 2014, the rate of return on USDIA at current cost was 8.5 percent, and the rate of return on FDIUS at current cost was 5.5 percent (U.S. Bureau of Economic Analysis, 2017a, 2017b). McGrattan and Prescott (2010) focus on the exclusion of intangible assets in the denominator as a source of the gap. Bridgman (2014) focuses on the exclusion of intangible assets and repatriation taxes as a source of the gap. Both studies find a much narrower gap when they make adjustments for the exclusions. Following calculations in table 1 of U.S. Bureau of Economic Analysis (2017a), we calculate an adjusted rate of return on USDIA at current cost using the adjusted income on USDIA reported in table 1.1 and the adjusted beginning and ending direct 
investment position assets reported in appendix table A1. The adjusted and unadjusted returns are presented in figure 5. Since our formulary adjustments decrease the numerator of the calculation by a larger percentage than the denominator, the adjusted rate of return on USDIA of 3.5 percent is less than half of the unadjusted rate of 8.5 percent. In addition, the adjusted rate of return on USDIA is closer to the rate of return on FDIUS for the year. ${ }^{21}$

Figure 6 presents adjusted and unadjusted external balances from the current account of the U.S. balance of payments presented in table 1.1. Balances are presented as a percentage of expenditure-based GDP or GNI presented in table 3.1. Since we treat our adjustments as an implied increase in exports of services, there is no effect on the measured goods balance. However, the goods balance as a percentage of GDP declines slightly because of the implied increase in services exports and the resulting increase in GDP. As a percentage of GDP, the services balance almost doubles from 1.5 percent to 2.9 percent, which increases the trade balance from negative 2.8 percent to negative 1.3 percent. As a percentage of GNI, the primary income balance decreases from 1.2 percent to negative 0.4 percent. The only effect our adjustments have on the current account balance is the decline of $\$ 26.4$ billion, which reduces the current account balance from negative 2.1 percent of GNI to negative 2.2 percent of GNI.

\section{Conclusions}

Offshore profit shifting accomplished through complex global structuring that includes holding companies and special purpose entities imposes challenges for the treatment of MNEs in the SNA and BPM frameworks. The international guidelines recommend that transactions and other flows with a holding company or special purpose entity be recognized in economic accounts if the holding company or special purpose entity is resident in an economy other than its parent. Using results from Guvenen et al. (2017), this paper empirically demonstrates the effects on the U.S. economic accounts in 2014 of using a method of formulary apportionment in lieu of separate accounting, which results in a reattribution of operating surplus and income on USDIA from foreign affiliates to U.S. parents.

\footnotetext{
${ }^{21}$ The unadjusted rate of return of 8.5 percent is closer to the long-run rate of return on an investment portfolio of listed stocks such as the S\&P 500. Given the resources that MNEs devote to actively managing their operations abroad, management and owners are unlikely to accept a rate of return that falls significantly short of a return on a passive portfolio over the long run. In order to draw a reliable conclusion regarding the accuracy of the unadjusted rate of return over the adjusted rate of return would require an analysis over a much longer period of time than the single year we present here.
} 
For 2014, we find notable changes in key economic accounting measures throughout the U.S. economic accounts, which may have significant implications for their analytic uses. Our adjustments yield a 3.5 percent increase in U.S. operating surplus, which generates a 1.5 percent increase in U.S. GDP as a result of an implied increase in output that is used as services exports. We find a 33.5 percent decrease in U.S. income receivable from the rest of world, which is overwhelmingly attributable to a decrease in earnings on USDIA with a small amount attributable to net interest receivable on USDIA. In dollar amounts, the increase in operating surplus is offset by a larger decrease in income receivable from the rest of world. As a result of these offsetting effects, U.S. GNI and gross national disposable income decrease by 0.1 percent while gross national saving decreases by 0.8 percent and national borrowing increases by 6.9 percent. Finally, net worth in the balance sheet decreases by 0.3 percent.

The results for analytic uses include a decrease for the labor share of income of 1.4 to 2.4 percentage points and a decrease for the return on USDIA of 5.0 percentage points. The results for analytic uses also include an increase for the trade in services balance as a percentage of GDP of 1.4 percentage points and an increase for the return on domestic non-financial business of 1.3 percentage points. Changes for the national saving rate and the current account balance as a percentage of GDP are negligible. 


\section{References}

Altshuler, Rosanne and Harry Grubert. 2010. Formula Apportionment: Is it better than the Current System and Are there better Alternatives? National Tax Journal, 63(4), pp. 1145-1184.

Avi-Yonah, Reuven S. 2010. Between Formulary Apportionment and the OECD Guidelines: A Proposal for Reconciliation. World Tax Journal, 2(1), pp. 3-18.

Avi-Yonah, Reuven S. and Kimberly A. Clausing. 2007. Reforming Corporate Taxation in a Global Economy: A Proposal to Adopt Formulary Apportionment. The Hamilton Project Discussion Paper 2007-08.

Baldwin, Robert E. and Fukunari Kimura. 1998. Measuring U.S. International Goods and Services Transactions, in Geography and Ownership Bases for Economic Accounting, Robert E. Baldwin, Robert E. Lipsey, and David J. Richards, eds. The University of Chicago Press, Chicago, IL, pp. 9-48.

Bridgman, Benjamin. 2018. Is Labor's Loss Capital's Gain? Gross versus Net Labor Shares. Macroeconomic Dynamics, 22(8), pp. 1-18.

Bridgman, Benjamin. 2014. Do Intangible Assets Explain High U.S. Foreign Direct Investment Returns? Journal of Macroeconomics, 40(A), pp. 159-171.

Brynjolfsson, Erik and Andrew McAfee. 2011. Race against the Machine: How the Digital Revolution is Accelerating Innovation, Driving Productivity, and Irreversibly Transforming Employment and the Economy. Lexington, MA: Digital Frontier Press.

Byrne, David M., John G. Fernald, and Marshall B. Reinsdorf. 2016. Does the United States have a Productivity Slowdown or a Measurement Problem? Brookings Paper on Economic Activity, March 10-11.

Byrne, David M., Stephen D. Oliner, and Daniel E. Sichel. 2015. How Fast are Semiconductor Prices Falling? NBER Working Paper No. 21074.

Clausing, Kimberly A. 2016. The Effect of Profit Shifting on the Corporate Tax Base in the United States and Beyond. National Tax Journal, 69(4), 905-934.

Cooper, Michael, John McClelland, James Pearce, Richard Prisinzano, Joseph Sullivan, Dany Yagan, Owen Zidar, and Eric Zwick. 2015. Business Income in the United States: Who Owns it and How Much Tax do They Pay? NBER Working Paper No. 21651.

Corrado, Carol, Charles Hulten, and Daniel Sichel. 2009. Intangible Capital and U.S. Economic Growth. Review of Income and Wealth, 55(3), pp. 661-685.

DeBacker, Jason M. and Richard Prisinzano. 2015. The Rise of Partnerships. Tax Notes, 147(13), pp. 1563-1575.

Dharmapala, Dhammika. 2014. What Do We Know about Base Erosion and Profit Shifting? A Review of the Empirical Literature, Fiscal Studies, 35(4), pp. 421-448.

Dowd, Tim, Paul Landefeld, and Anne Moore. 2017. Profit Shifting of U.S. Multinationals. Journal of Public Economics, 148, pp. 1-13.

Eisfeldt, Andrea L and Dimitris Papanikolaou. 2013. Organization Capital and the CrossSection of Expected Returns. Journal of Finance, 68(4), pp. 1365-1406.

Fernald, John. 2014. Productivity and Potential Output Before, During, and After the Great Recession. NBER Working Paper No. 20248.

Fuest, Clemens, Thomas Hemmelgarn and Fred Ramb. 2007. How Would the Introduction of an EU-Wide Formula Apportionment Affect the Distribution and Size of the Corporate Tax Base? International Tax and Public Finance, 14(5), pp. 605-626. 
Gordon, Roger and John D. Wilson. 1986. An Examination of Multi-jurisdictional Corporate Income Taxation under Formulary Apportionment. Econometrica, 54(6), pp. 1,357-1,373.

Gresik, Thomas A. 2001. The Taxing Task of Taxing Transnationals. Journal of Economic Literature, 39(3), pp. 800-838.

Guvenen, Fatih, Raymond J. Mataloni Jr., Dylan G. Rassier, and Kim J. Ruhl. 2017. Offshore Profit Shifting and Domestic Productivity Measurement. NBER Working Paper No. 23324.

Hines, James R. 2010. Income Misattribution under Formula Apportionment. European Economic Review, 54(1), pp. 108-120.

Hines, Jr., James R. and Eric M. Rice. 1994. Fiscal Paradise: Foreign Tax Havens and American Business, Quarterly Journal of Economics, 109(1), pp. 149-182.

Karabarbounis, Loukas and Brent Neiman (2014). The Global Decline of the Labor Share. Quarterly Journal of Economics, 129(1), pp. 61-103.

Kimura, Fukunari, and Robert E. Baldwin. 1998. Application of a Nationality-Adjusted Net Sales and Value-Added Framework: The Case of Japan, in Geography and Ownership Bases for Economic Accounting, Robert E. Baldwin, Robert E. Lipsey, and David J. Richards, eds. The University of Chicago Press, Chicago, IL, pp. 49-82.

Landefeld, J. Steven, Obie G. Wichard, and Jeff H. Lowe. 1993. Alternative Frameworks for U.S. International Transactions, Survey of Current Business, 73(12), pp. 50-61.

Lipsey, Robert E. 2010. Measuring the Location of Production in a World of Intangible Productive Assets, FDI, and Intrafirm Trade. Review of Income and Wealth, 56(1), pp. S99-S110.

McGrattan, Ellen R. and Edward C. Prescott. 2010. Technology Capital and the U.S. Current Account. American Economic Review, 100(4), pp. 1493-1522.

Mokyr, Joel. 2014. "Secular Stagnation? Not in Your Life" in Secular Stagnation: Facts, Causes and Cures, Coen Teulings and Richard Baldwin, eds. London: CEPR Press.

Moulton, Brent R. and Peter van de Ven. 2018. Addressing the Challenges of Globalization in National Accounts. Paper prepared for the NBER-CRIW conference on The Challenges of Globalization in the Measurement of National Accounts.

Organization for Economic Cooperation and Development. 2015a. Measuring and Monitoring BEPS, Action 11 - 2015 Final Report. OECD Publishing, Paris.

Organization for Economic Cooperation and Development. 2015b. Transfer Pricing Documentation and Country-by-Country Reporting, Action 13 - 2015 Final Report. OECD Publishing, Paris.

Osborne, Sarah and Bonnie A. Retus. 2017. Returns for Domestic Nonfinancial Business. Survey of Current Business, 97(12), pp. 1-6.

Rassier, Dylan G. 2017. Improving the SNA Treatment of Multinational Enterprises. Review of Income and Wealth, 63(s2), pp. S287-S320.

Rassier, Dylan G. and Jennifer Koncz-Bruner. 2015. “A Formulary Approach for Attributing Measured Production to Foreign Affiliates of U.S. Parents” in Measuring Globalization: Better Trade Statistics for Better Policy, Susan N. Houseman and Michael Mandel, eds. W.E. Upjohn Institute for Employment Research.

Reinsdorf, Marshall B. 2004. Alternative Measures of Personal Saving. Survey of Current Business, 84(9), pp. 17-27.

Runkel, Marco and Guttorm Schjelderup. 2011. The Choice of Apportionment Factors under Formula Apportionment. International Economic Review, 52(3), pp. 913-934. 
Sanchirico, Chris William. 2015. As American as Apple Inc.: International Tax and Ownership Nationality. Tax Law Review, 68(2), pp. 207-274.

Syverson, Chad. 2017. Challenges to Mismeasurement Explanations for the U.S. Productivity Slowdown. Journal of Economic Perspectives, 31(2), pp. 165-186.

United Nations; Eurostat; and Organisation for Economic Co-operation and Development. 2011. The Impact of Globalization on National Accounts. New York and Geneva: United Nations.

United States Bureau of Economic Analysis. 2017a. U.S. Direct Investment Abroad for 20142016: Detailed Historical Cost Positions and Related Financial Transactions and Income Flows. Survey of Current Business, 97(9).

United States Bureau of Economic Analysis. 2017b. Foreign Direct Investment in the United States for 2014-2016: Detailed Historical Cost Positions and Related Financial Transactions and Income Flows. Survey of Current Business, 97(9).

United States Department of the Treasury. 2007. Report to the Congress on Earnings Stripping, Transfer Pricing, and U.S. Income Tax Treaties. 
Table 1.1: BPM Balance of Payments Current Account and Capital Account for the U.S.

\begin{tabular}{|c|c|c|c|c|c|c|c|c|c|c|c|c|c|}
\hline \multirow[b]{3}{*}{ 藇 } & \multicolumn{5}{|l|}{ Credits } & \multirow[b]{3}{*}{ 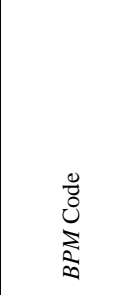 } & \multirow[b]{3}{*}{$\begin{array}{l}\tilde{D} \\
0 \\
\sum_{n}\end{array}$} & & \multicolumn{5}{|l|}{ Debits } \\
\hline & \multirow[b]{2}{*}{ 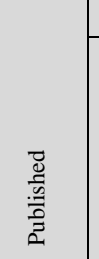 } & \multicolumn{3}{|c|}{ Adjustments } & \multirow[b]{2}{*}{ 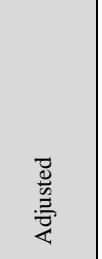 } & & & & \multirow[b]{2}{*}{ 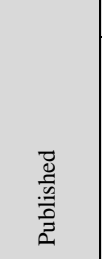 } & \multicolumn{3}{|c|}{ Adjustments } & \multirow[b]{2}{*}{ 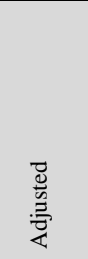 } \\
\hline & & 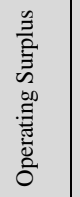 & $\begin{array}{l}\text { 足 } \\
\text { 竘 } \\
\text { 矛 }\end{array}$ & 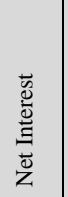 & & & & & & 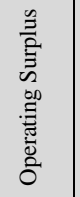 & $\begin{array}{l}\text { 品 } \\
\text { 节 } \\
\text { 矛 }\end{array}$ & 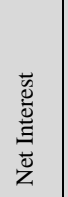 & \\
\hline \multirow{3}{*}{1} & (1) & (2) & (3) & (4) & (5) & & & & (6) & (7) & (8) & (9) & (10) \\
\hline & & & & & & & B12 & Current account balance & -373.8 & 255.5 & -273.1 & -8.7 & -400.2 \\
\hline & & & & & & & & Goods and Services Account & & & & & \\
\hline \multirow{2}{*}{$\begin{array}{l}2 \\
3\end{array}$} & $2,375.9$ & 255.5 & & & $2,631.4$ & $1 . \mathrm{A}$ & $\mathrm{P} 6 / \mathrm{P} 7$ & Transactions in goods and services & $2,866.2$ & & & & $2,866.2$ \\
\hline & & & & & & & B11 & Balance on goods and services & -490.3 & 255.5 & & & -234.9 \\
\hline \multirow{2}{*}{$\begin{array}{l}4 \\
5\end{array}$} & $1,634.0$ & & & & $1,634.0$ & 1.A.a & P61/P71 & Goods & $2,385.5$ & & & & $2,385.5$ \\
\hline & & & & & & & & Balance on trade in goods & -751.5 & & & & -751.5 \\
\hline 6 & $1,611.0$ & & & & $1,611.0$ & 1.A.a.1 & & General merchandise & $2,370.0$ & & & & $2,370.0$ \\
\hline 7 & 0.3 & & & & 0.3 & 1.A.a.2 & & Net exports of goods under merchanting & & & & & \\
\hline 8 & 22.7 & & & & 22.7 & 1.A.a.3 & & Nonmonetary gold & 15.5 & & & & 15.5 \\
\hline 9 & 741.9 & 255.5 & & & 997.4 & 1.A.b & P72/P82 & Services & 480.8 & & & & 480.8 \\
\hline 10 & & & & & & & & Balance on trade in services & 261.2 & 255.5 & & & 516.6 \\
\hline 11 & 21.1 & & & & 21.1 & 1.A.b.2 & & Maintenance and repair & 7.5 & & & & 7.5 \\
\hline 12 & 282.6 & & & & 282.6 & 1.A.b.3-4 & & Transport and travel & 199.9 & & & & 199.9 \\
\hline 13 & 124.3 & & & & 124.3 & 1.A.b.6-7 & & Insurance and finance & 75.9 & & & & 75.9 \\
\hline 14 & 129.7[ & 255.5 & & & 385.2 & 1.A.b.8 & & Charges for the use of intellectual property & 42.0 & & & & 42.0 \\
\hline 15 & 34.7 & & & & 34.7 & 1.A.b.9 & & Telecommunications and information & 36.5 & & & & 36.5 \\
\hline 16 & 128.9 & & & & 128.9 & 1.A.b.10 & & Other business services & 94.8 & & & & 94.8 \\
\hline \multirow[t]{2}{*}{17} & 20.5 & & & & 20.5 & 1.A.b.12 & & Government goods and services & 24.2 & & & & 24.2 \\
\hline & & & & & & & & Primary Income Account & & & & & \\
\hline 18 & 807.1 & & -273.1 & -8.7 & 525.3 & $1 . \mathrm{B}$ & & Transactions in primary income & 596.4 & & & & 596.4 \\
\hline 19 & & & & & & & & Balance on primary income & 210.8 & & -273.1 & -8.7 & -71.1 \\
\hline 20 & 6.5 & & & & 6.5 & 1.B.1 & D1 & Compensation of employees & 17.1 & & & & 17.1 \\
\hline 21 & 800.6 & & -273.1 & -8.7 & 518.8 & 1.B.2 & & Investment income & 579.3 & & & & 579.3 \\
\hline 22 & 464.6 & & -273.1 & -8.7 & 182.7 & 1.B.2.1 & D4D & Direct investment & 187.9 & & & & 187.9 \\
\hline 23 & 455.6 & & -273.1 & & 182.5 & 1.B.2.1.1 & & Income on equity & 162.4 & & & & 162.4 \\
\hline 24 & 144.0 & & & & 144.0 & 1.B.2.1.1.1 & $\mathrm{D} 42 \mathrm{D}$ & Dividends and withdrawals & 67.6 & & & & 67.6 \\
\hline 25 & 311.6 & & -273.1 & $\longrightarrow$ & 38.5 & 1.B.2.1.1.2 & D43D & Reinvested earnings & 94.8 & & & & 94.8 \\
\hline 26 & 9.0 & & & -8.7 & 0.3 & 1.B.2.1.2 & D41D & Interest & 25.4 & & & & 25.4 \\
\hline 27 & 305.0 & & & & 305.0 & 1.B.2.2 & D4P & Portfolio investment & 377.5 & & & & 377.5 \\
\hline 28 & 30.7 & & & & 30.7 & 1.B.2.3 & $\mathrm{D} 4 \mathrm{O}$ & Other investment & 13.9 & & & & 13.9 \\
\hline \multirow[t]{2}{*}{29} & 0.3 & & & & 0.3 & 1.B.2.4 & $\mathrm{D} 4 \mathrm{R}$ & Reserve assets & & & & & \\
\hline & & & & & & & & Secondary Income Account & & & & & \\
\hline 30 & 140.1 & & & & 140.1 & 1.C & & Transactions in secondary income & 234.3 & & & & 234.3 \\
\hline \multirow[t]{2}{*}{31} & & & & & & & & Balance on secondary income & -94.2 & & & & -94.2 \\
\hline & & & & & & 2 & & Capital Account & & & & & \\
\hline 32 & & & & & & & & Capital account balance & 0.0 & & & & 0.0 \\
\hline 33 & & & & & & 2.1 & N2 & Gross acquisitions & & & & & \\
\hline 34 & 0.0 & & & & 0.0 & 2.2 & D9 & Capital transfers & 0.0 & & & & 0.0 \\
\hline 35 & & & & & & & B9 & $\begin{array}{l}\text { Net lending / borrowing (current and capital } \\
\text { account) }\end{array}$ & -373.8 & 255.5 & -273.1 & -8.7 & -400.2 \\
\hline
\end{tabular}


Table 1.2: BPM Balance of Payments Financial Account for the U.S.

\begin{tabular}{|c|c|c|c|c|c|c|c|c|c|c|c|c|c|}
\hline \multirow[b]{3}{*}{ 号 } & \multicolumn{5}{|c|}{ Net Acquisition of Financial Assets } & \multirow[b]{3}{*}{ 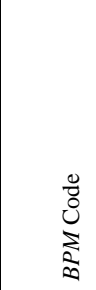 } & \multirow[b]{3}{*}{ 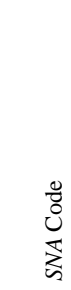 } & & \multicolumn{5}{|c|}{ Net Incurrence of Liabilities } \\
\hline & \multirow[b]{2}{*}{ 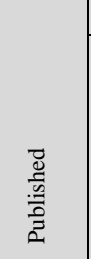 } & \multicolumn{3}{|c|}{ Adjustments } & \multirow[b]{2}{*}{ 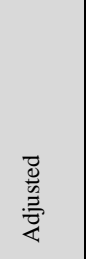 } & & & & \multirow[b]{2}{*}{ 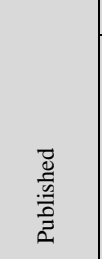 } & \multicolumn{3}{|c|}{ Adjustments } & \multirow[b]{2}{*}{ 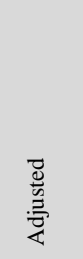 } \\
\hline & & 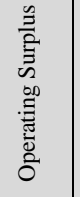 & $\begin{array}{l}\text { 嵒 } \\
\text { 宸 } \\
\text { 岱 }\end{array}$ & 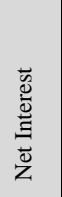 & & & & & & 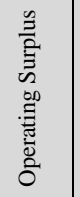 & $\begin{array}{l}\text { 品 } \\
\text { 节 } \\
\text { 氙 }\end{array}$ & 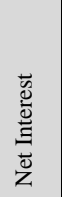 & \\
\hline & (1) & (2) & (3) & (4) & (5) & & & & (6) & (7) & (8) & (9) & (10) \\
\hline 1 & & & & & & & & Stat. disc. (current and capital-financial account) & -47.0 & & & & -47.0 \\
\hline 2 & & & & & & & B9 & Net lending / borrowing (financial account) & -326.8 & 255.5 & -273.1 & -8.7 & -353.2 \\
\hline 3 & 313.5 & 255.5 & -273.1 & -8.7 & 287.2 & 3.1 & FD & Direct investment & 212.3 & & & & 212.3 \\
\hline 4 & 330.4 & 255.5 & -273.1 & -8.7 & 304.0 & 3.1 .1 & F5D & Equity & 146.4 & & & & 146.4 \\
\hline 5 & 18.8 & 255.5 & & -8.7 & 265.5 & 3.1.1.1 & & Equity other than reinvestment of earnings & 51.6 & & & & 51.6 \\
\hline 6 & 311.6 & & -273.1 & & 38.5 & 3.1.1.2 & & Reinvestment of earnings & 94.8 & & & & 94.8 \\
\hline 7 & -16.8 & & & & -16.8 & 3.1.2 & F3D & Debt instruments & 65.9 & & & & 65.9 \\
\hline 8 & 582.7 & & & & 582.7 & 3.2 & FP & Portfolio investment & 703.5 & & & & 703.5 \\
\hline 9 & 431.6 & & & & 431.6 & 3.2.1 & F5P & Equity & 154.3 & & & & 154.3 \\
\hline 10 & 151.1 & & & & 151.1 & 3.2.2 & F3P & Debt securities & 549.2 & & & & 549.2 \\
\hline 11 & & & & & & 3.3 & F7F & Financial derivatives & 54.3 & & & & 54.3 \\
\hline 12 & -99.2 & & & & -99.2 & 3.4 & FO & Other investment & 150.2 & & & & 150.2 \\
\hline 13 & -161.8 & & & & -161.8 & 3.4 .2 & F2O & Currency and deposits & 59.7 & & & & 59.7 \\
\hline 14 & 68.4 & & & & 68.4 & 3.4.3 & $\mathrm{F} 4 \mathrm{O}$ & Loans & 77.9 & & & & 77.9 \\
\hline 15 & -5.8 & & & & -5.8 & 3.4.4-6 & & Other & 12.6 & & & & 12.6 \\
\hline 16 & -3.6 & & & & -3.6 & 3.5 & FR & Reserves & & & & & \\
\hline 17 & 0.0 & & & & 0.0 & 3.5 .1 & F11 & Monetary gold & & & & & \\
\hline 18 & 0.0 & & & & 0.0 & 3.5 .2 & F12 & Special drawing rights & & & & & \\
\hline 19 & -3.8 & & & & -3.8 & 3.5.3 & & Reserve position in the IMF & & & & & \\
\hline 20 & 0.2 & & & & 0.2 & 3.5 .4 & & Other & & & & & \\
\hline 21 & 793.5 & 255.5 & -273.1 & -8.7 & 767.1 & 3 & $\mathrm{~F}$ & Totals & $1,120.3$ & & & & $1,120.3$ \\
\hline
\end{tabular}


Table 2.1: BPM International Investment Position for the U.S.

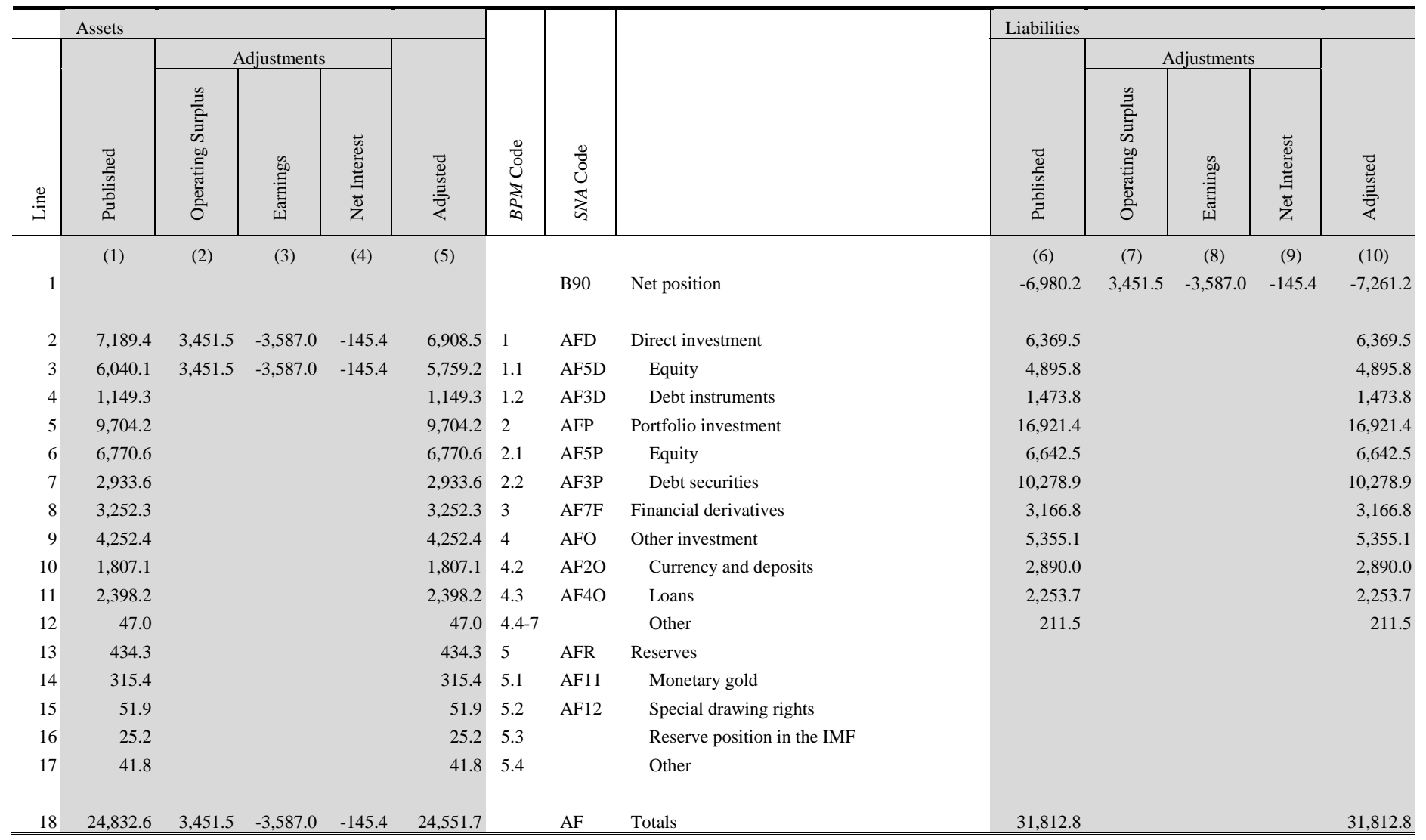

Table 2.2: BPM Direct Investment Position for the U.S.

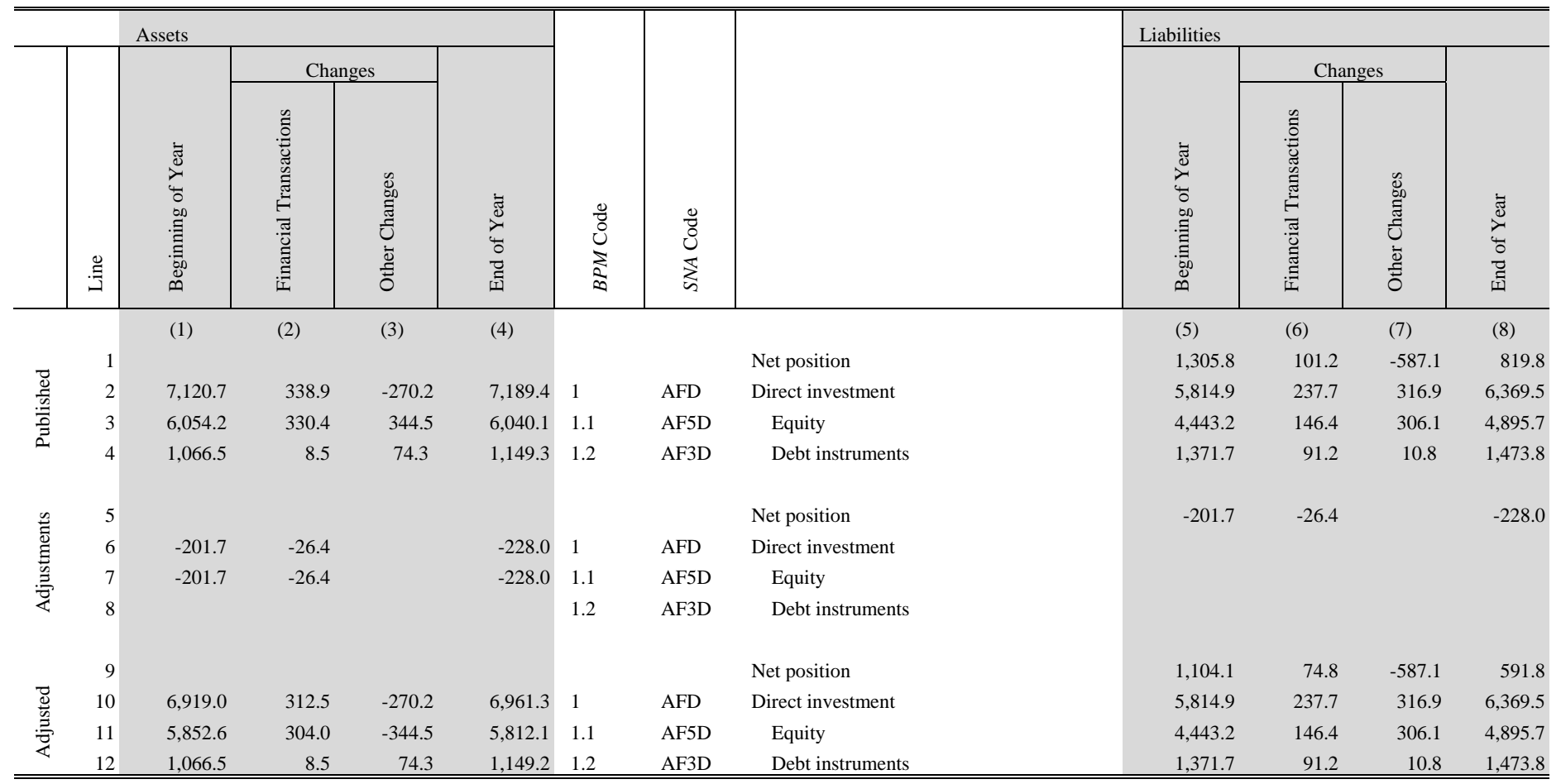




\section{Table 3.1: SNA Current Accounts for the U.S. - Uses}

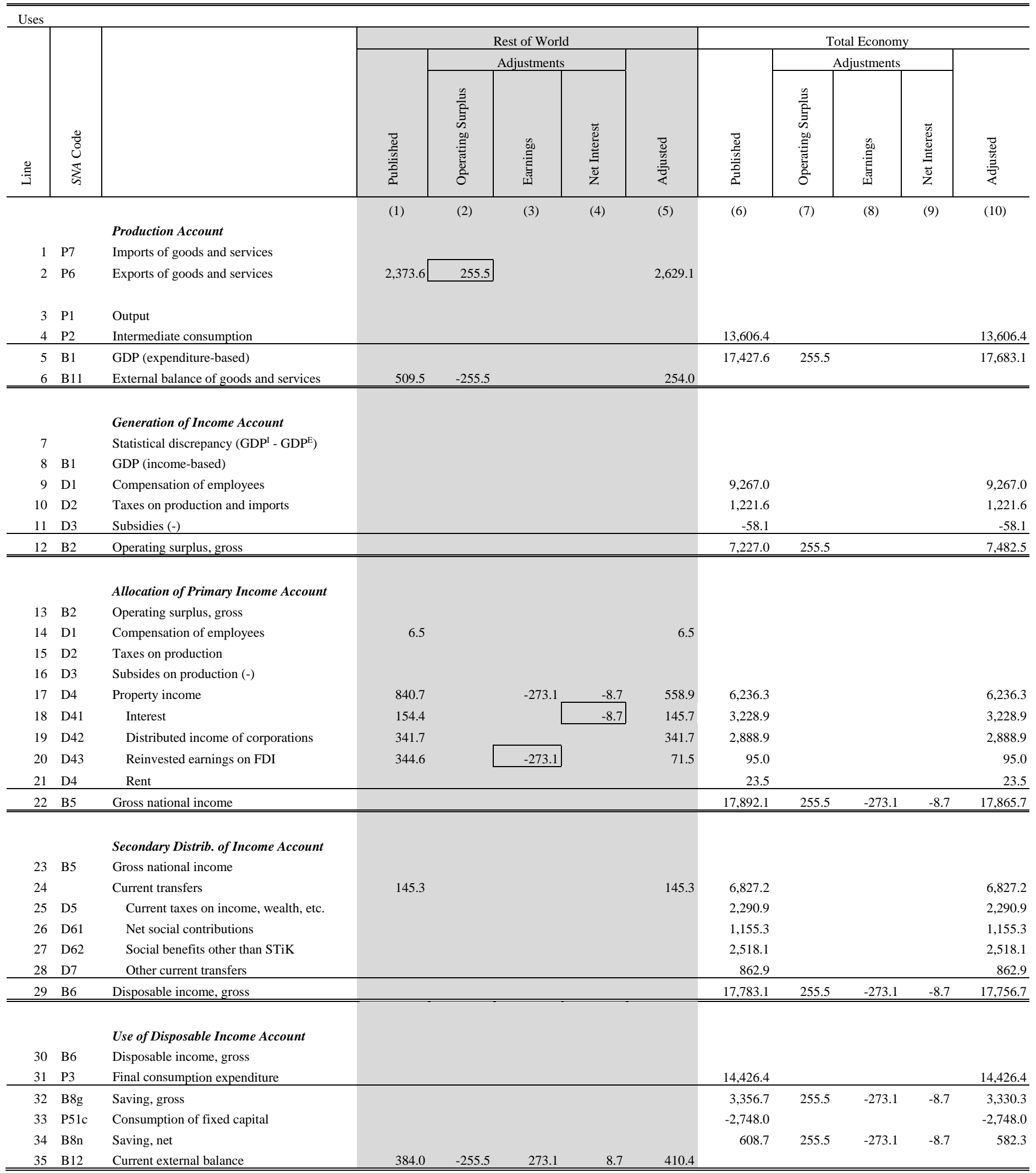


Table 3.1: SNA Current Accounts for the U.S. - Resources

\begin{tabular}{|c|c|c|c|c|c|c|c|c|c|c|c|c|}
\hline \multicolumn{13}{|c|}{ Resources } \\
\hline \multirow[b]{3}{*}{.$\leftrightarrows$} & \multirow[b]{3}{*}{ 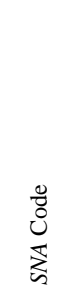 } & & \multicolumn{5}{|c|}{ Rest of World } & \multicolumn{5}{|c|}{ Total Economy } \\
\hline & & & \multirow[b]{2}{*}{ 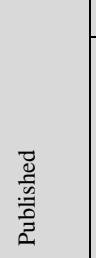 } & \multicolumn{3}{|c|}{ Adjustments } & \multirow[b]{2}{*}{ 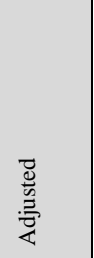 } & \multirow[b]{2}{*}{ 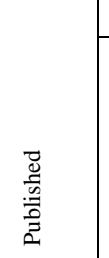 } & \multicolumn{3}{|c|}{ Adjustments } & \multirow[b]{2}{*}{ 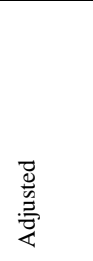 } \\
\hline & & & & 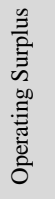 & 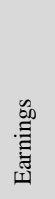 & 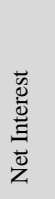 & & & 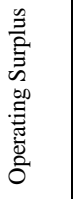 & 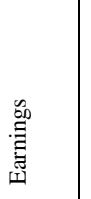 & 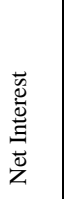 & \\
\hline & & & (1) & (2) & (3) & (4) & (5) & (6) & (7) & (8) & (9) & $(10)$ \\
\hline & & Production Account & & & & & & & & & & \\
\hline 1 & P7 & Imports of goods and services & $2,883.1$ & & & & $2,883.1$ & & & & & \\
\hline 2 & P6 & Exports of goods and services & & & & & & & & & & \\
\hline 3 & $\mathrm{P} 1$ & Output & & & & & & $31,034.0 \longleftarrow$ & 255.5 & & & $31,289.5$ \\
\hline 4 & $\mathrm{P} 2$ & Intermediate consumption & & & & & & & & & & \\
\hline 5 & $\mathrm{~B} 1$ & GDP (expenditure-based) & & & & & & & & & & \\
\hline \multirow[t]{2}{*}{6} & $\mathrm{~B} 11$ & External balance of goods and services & & & & & & & & & & \\
\hline & & Generation of Income Account & & & & & & & & & & \\
\hline 7 & & Statistical discrepancy $\left(\mathrm{GDP}^{\mathrm{I}}-\mathrm{GDP}^{\mathrm{E}}\right)$ & & & & & & 229.9 & & & & 229.9 \\
\hline 8 & $\mathrm{~B} 1$ & GDP (income-based) & & & & & & $17,657.5$ & 255.5 & & & $17,913.0$ \\
\hline 9 & D1 & Compensation of employees & & & & & & & & & & \\
\hline 10 & D2 & Taxes on production and imports & & & & & & & & & & \\
\hline 11 & D3 & Subsidies (-) & & & & & & & & & & \\
\hline \multirow[t]{2}{*}{12} & $\mathrm{~B} 2$ & Operating surplus, gross & & & & & & & & & & \\
\hline & & Allocation of Primary Income Account & & & & & & & & & & \\
\hline 13 & B2 & Operating surplus, gross & & & & & & $7,227.0$ & 255.5 & & & $7,482.5$ \\
\hline 14 & D1 & Compensation of employees & 17.1 & & & & 17.1 & $9,256.5$ & & & & $9,256.5$ \\
\hline 15 & D2 & Taxes on production & & & & & & $1,221.6$ & & & & $1,221.6$ \\
\hline 16 & D3 & Subsides on production (-) & & & & & & -58.1 & & & & -58.1 \\
\hline 17 & D4 & Property income & 595.5 & & & & 595.5 & $6,481.4$ & & -273.1 & -8.7 & $6,199.6$ \\
\hline 18 & D41 & Interest & 306.6 & & & & 306.6 & $3,076.5$ & & & -8.7 & $3,067.8$ \\
\hline 19 & D42 & Distributed income of corporations & 193.9 & & & & 193.9 & $3,036.8$ & & & & $3,036.8$ \\
\hline 20 & D43 & Reinvested earnings on FDI & 95.0 & & & & 95.0 & 344.6 & & -273.1 & & 71.5 \\
\hline 21 & D4 & Rent & & & & & & 23.5 & & & & 23.5 \\
\hline \multirow[t]{2}{*}{22} & $\mathrm{~B} 5$ & Gross national income & & & & & & & & & & \\
\hline & & Secondary Distrib. of Income Account & & & & & & & & & & \\
\hline 23 & B5 & Gross national income & & & & & & $17,892.1$ & 255.5 & -273.1 & -8.7 & $17,865.7$ \\
\hline 24 & & Current transfers & 254.4 & & & & 254.4 & $6,718.2$ & & & & $6,718.2$ \\
\hline 25 & D5 & Current taxes on income, wealth, etc. & & & & & & $2,300.5$ & & & & $2,300.5$ \\
\hline 26 & D61 & Net social contributions & & & & & & $1,160.5$ & & & & $1,160.5$ \\
\hline 27 & D62 & Social benefits other than STiK & & & & & & $2,498.8$ & & & & $2,498.8$ \\
\hline 28 & D7 & Other current transfers & & & & & & 758.4 & & & & 758.4 \\
\hline \multirow[t]{2}{*}{29} & B6 & Disposable income, gross & & & & & & & & & & \\
\hline & & Use of Disposable Income Account & & & & & & & & & & \\
\hline 30 & B6 & Disposable income, gross & & & & & & $17,783.1$ & 255.5 & -273.1 & -8.7 & $17,756.7$ \\
\hline 31 & P3 & Final consumption expenditure & & & & & & & & & & \\
\hline 32 & B8g & Saving, gross & & & & & & & & & & \\
\hline 33 & P51c & Consumption of fixed capital & & & & & & & & & & \\
\hline 34 & B8n & Saving, net & & & & & & & & & & \\
\hline 35 & $\mathrm{~B} 12$ & Current external balance & & & & & & & & & & \\
\hline
\end{tabular}




\section{Table 3.2: SNA Accumulation Accounts for the U.S. - Changes in Assets}

\begin{tabular}{|c|c|c|c|c|c|c|c|c|c|c|c|c|}
\hline \multicolumn{13}{|c|}{ Changes in Assets } \\
\hline \multirow[b]{3}{*}{.} & \multirow[b]{3}{*}{ 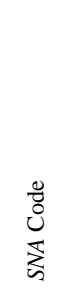 } & & \multirow[b]{3}{*}{ 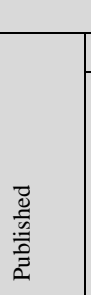 } & \multicolumn{4}{|c|}{ Rest of World } & \multicolumn{5}{|c|}{ Total Economy } \\
\hline & & & & \multicolumn{3}{|c|}{ Adjustments } & \multirow[b]{2}{*}{ 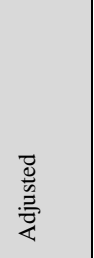 } & \multirow[b]{2}{*}{ 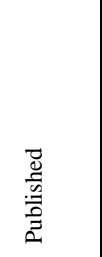 } & \multicolumn{3}{|c|}{ Adjustments } & \multirow[b]{2}{*}{ 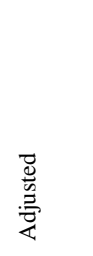 } \\
\hline & & & & 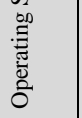 & 恕 & 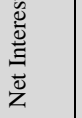 & & & 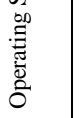 & 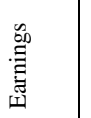 & 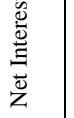 & \\
\hline & & & (1) & $(2)$ & (3) & (4) & (5) & (6) & (7) & (8) & (9) & $(10)$ \\
\hline & & Capital Account & & & & & & & & & & \\
\hline 36 & B8 & Saving, net & & & & & & & & & & \\
\hline 37 & B12 & Current external balance & & & & & & & & & & \\
\hline 38 & P5g & Gross capital formation & & & & & & $3,510.8$ & & & & $3,510.8$ \\
\hline 39 & P5n & Net capital formation & & & & & & 762.8 & & & & 762.8 \\
\hline 40 & P51g & Gross fixed capital formation & & & & & & $3,432.8$ & & & & $3,432.8$ \\
\hline 41 & P52 & Changes in inventories & & & & & & 78.0 & & & & 78.0 \\
\hline 42 & P51c & Consumption of fixed capital & & & & & & $-2,748.0$ & & & & $-2,748.0$ \\
\hline 43 & D9r & Capital transfers, receivable & & & & & & & & & & \\
\hline 44 & D9p & Capital transfers, payable & & & & & & & & & & \\
\hline 45 & B101 & $\begin{array}{l}\text { Changes in net worth due to saving and } \\
\text { capital transfers }\end{array}$ & & & & & & & & & & \\
\hline 46 & & Reverse stat. disc. (GDP ${ }^{\mathrm{I}}$ - GDP $\left.{ }^{\mathrm{E}}\right)$ & & & & & & & & & & \\
\hline \multirow[t]{2}{*}{47} & B9 & Net lending / borrowing (capital account) & 384.4 & -255.5 & 273.1 & 8.7 & 410.8 & -384.4 & 255.5 & -273.1 & -8.7 & -410.8 \\
\hline & & Financial Account & & & & & & & & & & \\
\hline 48 & & Stat. disc. (capital-financial account) & & & & & & & & & & \\
\hline 49 & B9 & Net lending / borrowing (financial account) & & & & & & & & & & \\
\hline 50 & & Net acquisition of financial assets/liabilities & $1,150.6$ & & & & $1,150.6$ & $5,465.5$ & 255.5 & -273.1 & -8.7 & $5,439.1$ \\
\hline 51 & $\mathrm{~F} 1$ & Monetary gold and SDRs & 0.0 & & & & 0.0 & 0.0 & & & & 0.0 \\
\hline 52 & F2 & Currency and deposits & 101.1 & & & & 101.1 & 843.7 & & & & 843.7 \\
\hline 53 & F3 & Debt securities & 533.6 & & & & 533.6 & 802.5 & & & & 802.5 \\
\hline 54 & $\mathrm{~F} 4$ & Loans & 136.7 & & & & 136.7 & 964.3 & & & & 964.3 \\
\hline 55 & F51 & Equity & 331.9 & & & & 331.9 & 805.0 & 255.5 & -273.1 & -8.7 & 778.6 \\
\hline 56 & F52 & Investment fund shares & 34.7 & & & & 34.7 & 282.0 & & & & 282.0 \\
\hline 57 & F6 & Insurance, pension and stand. guar. sch. & 0.0 & & & & 0.0 & 651.4 & & & & 651.4 \\
\hline \multirow[t]{2}{*}{58} & F8 & Other receivables/payables & 12.6 & & & & 12.6 & $1,116.6$ & & & & $1,116.6$ \\
\hline & & Other Changes in Vol. of Assets Account & & & & & & & & & & \\
\hline \multirow[t]{2}{*}{59} & $\mathrm{~B} 102$ & Changes in net worth due to OCVA & & & & & & & & & & \\
\hline & & Revaluation Account & & & & & & & & & & \\
\hline 60 & AN & Non-financial assets & & & & & & $3,064.5$ & & & & $3,064.5$ \\
\hline 61 & $\mathrm{AF}$ & Financial assets/liabilities & 680.7 & & & & 680.7 & $4,183.5$ & & & & $4,183.5$ \\
\hline 62 & AF1 & Monetary gold and SDRs & -3.2 & & & & -3.2 & -3.3 & & & & -3.3 \\
\hline 63 & AF2 & Currency and deposits & -0.2 & & & & -0.2 & -1.7 & & & & -1.7 \\
\hline 64 & AF3 & Debt securities & 53.3 & & & & 53.3 & 311.7 & & & & 311.7 \\
\hline 65 & AF4 & Loans & 0.0 & & & & 0.0 & 0.0 & & & & 0.0 \\
\hline 66 & AF5 & Equity & 608.0 & & & & 608.0 & $3,308.7$ & & & & $3,308.7$ \\
\hline 67 & AF5 & Investment fund shares & 23.1 & & & & 23.1 & 480.2 & & & & 480.2 \\
\hline 68 & AF6 & Insurance, pension and stand. guar. sch. & 0.0 & & & & 0.0 & 87.9 & & & & 87.9 \\
\hline 69 & AF8 & Other receivables/payables & -0.3 & & & & -0.3 & 0.0 & & & & 0.0 \\
\hline 70 & B103 & $\begin{array}{l}\text { Changes in net worth due to nominal holding } \\
\text { gains and losses }\end{array}$ & & & & & & & & & & \\
\hline
\end{tabular}


Table 3.2: SNA Accumulation Accounts for the U.S. - Changes in Liabilities or Net Worth

\begin{tabular}{|c|c|c|c|c|c|c|c|c|c|c|c|c|}
\hline \multicolumn{13}{|c|}{ Changes in Liabilities or Net Worth } \\
\hline \multirow[b]{3}{*}{$\stackrel{\Xi}{:}$} & \multirow[b]{3}{*}{$\begin{array}{l}\frac{\pi}{0} \\
\text { ju } \\
\text { is }\end{array}$} & & \multicolumn{5}{|c|}{ Rest of World } & \multicolumn{5}{|c|}{ Total Economy } \\
\hline & & & \multirow[b]{2}{*}{ 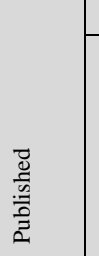 } & \multicolumn{3}{|c|}{ Adjustments } & \multirow[b]{2}{*}{ 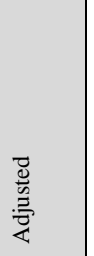 } & \multirow[b]{2}{*}{ 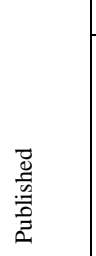 } & \multicolumn{3}{|c|}{ Adjustments } & \multirow[b]{2}{*}{ 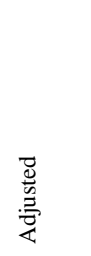 } \\
\hline & & & & 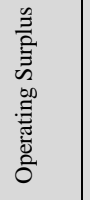 & $\begin{array}{l}\text { 品 } \\
\text { 端 } \\
\text { 空 }\end{array}$ & 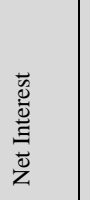 & & & 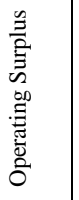 & $\begin{array}{l}\text { 品 } \\
\text { 音 } \\
\text { 穿 }\end{array}$ & 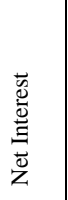 & \\
\hline & & & (1) & (2) & (3) & (4) & (5) & (6) & (7) & (8) & (9) & (10) \\
\hline & & Capital Account & & & & & & & & & & \\
\hline 36 & B8 & Saving, net & & & & & & 608.7 & 255.5 & -273.1 & -8.7 & 582.3 \\
\hline 37 & B12 & Current external balance & 384.0 & -255.5 & 273.1 & 8.7 & 410.4 & & & & & \\
\hline 38 & P5g & Gross capital formation & & & & & & & & & & \\
\hline 39 & P5n & Net capital formation & & & & & & & & & & \\
\hline 40 & P51g & Gross fixed capital formation & & & & & & & & & & \\
\hline 41 & P52 & Changes in inventories & & & & & & & & & & \\
\hline 42 & P51c & Consumption of fixed capital & & & & & & & & & & \\
\hline 43 & D9r & Capital transfers, receivable & 0.4 & & & & 0.4 & 110.6 & & & & 110.6 \\
\hline 44 & D9p & Capital transfers, payable & 0.0 & & & & 0.0 & -111.0 & & & & -111.0 \\
\hline 45 & B101 & $\begin{array}{l}\text { Changes in net worth due to saving and } \\
\text { capital transfers }\end{array}$ & 384.4 & -255.5 & 273.1 & 8.7 & 410.8 & 608.3 & 255.5 & -273.1 & -8.7 & 581.9 \\
\hline 46 & & Reverse stat. disc. (GDP ${ }^{\mathrm{I}}$-GDP $\left.{ }^{\mathrm{E}}\right)$ & & & & & & -229.9 & & & & -229.9 \\
\hline \multirow[t]{2}{*}{47} & B9 & Net lending / borrowing (capital account) & & & & & & & & & & \\
\hline & & Financial Account & & & & & & & & & & \\
\hline 48 & & Stat. disc. (capital-financial account) & 50.3 & & & & 50.3 & -45.4 & & & & -45.4 \\
\hline 49 & B9 & Net lending / borrowing (financial account) & 334.1 & -255.5 & 273.1 & 8.7 & 360.5 & -339.0 & 255.5 & -273.1 & -8.7 & -365.4 \\
\hline 50 & & Net acquisition of financial assets/liabilities & 816.5 & 255.5 & -273.1 & -8.7 & 790.1 & $5,804.5$ & & & & $5,804.5$ \\
\hline 51 & $\mathrm{~F} 1$ & Monetary gold and SDRs & 0.0 & & & & 0.0 & 0.0 & & & & 0.0 \\
\hline 52 & F2 & Currency and deposits & -122.6 & & & & -122.6 & 924.9 & & & & 924.9 \\
\hline 53 & F3 & Debt securities & 162.8 & & & & 162.8 & $1,173.3$ & & & & $1,173.3$ \\
\hline 54 & F4 & Loans & 49.2 & & & & 49.2 & 946.6 & & & & 946.6 \\
\hline 55 & F51 & Equity & 732.9[ & 255.5 & -273.1 & -8.7 & 706.5 & 404.1 & & & & 404.1 \\
\hline 56 & F52 & Investment fund shares & 0.0 & & & & 0.0 & 316.5 & & & & 316.5 \\
\hline 57 & F6 & Insurance, pension and stand. guar. sch. & 0.0 & & & & 0.0 & 651.3 & & & & 651.3 \\
\hline \multirow[t]{2}{*}{58} & F8 & Other receivables/payables & -5.8 & & & & -5.8 & $1,387.8$ & & & & $1,387.8$ \\
\hline & & Other Changes in Vol. of Assets Account & & & & & & & & & & \\
\hline \multirow[t]{2}{*}{59} & $\mathrm{~B} 102$ & Changes in net worth due to OCVA & -50.2 & & & & -50.2 & 339.6 & & & & 339.6 \\
\hline & & Revaluation Account & & & & & & & & & & \\
\hline 60 & AN & Non-financial assets & & & & & & & & & & \\
\hline 61 & $\mathrm{AF}$ & Financial assets/liabilities & -72.8 & & & & -72.8 & $3,837.7$ & & & & $3,837.7$ \\
\hline 62 & AF1 & Monetary gold and SDRs & -3.3 & & & & -3.3 & -3.2 & & & & -3.2 \\
\hline 63 & AF2 & Currency and deposits & -12.9 & & & & -12.9 & 0.0 & & & & 0.0 \\
\hline 64 & AF3 & Debt securities & 54.6 & & & & 54.6 & 0.0 & & & & 0.0 \\
\hline 65 & AF4 & Loans & 0.0 & & & & 0.0 & 0.0 & & & & 0.0 \\
\hline 66 & AF5 & Equity & -110.7 & & & & -110.7 & $3,245.2$ & & & & $3,245.2$ \\
\hline 67 & AF5 & Investment fund shares & 0.0 & & & & 0.0 & 507.9 & & & & 507.9 \\
\hline 68 & AF6 & Insurance, pension and stand. guar. sch. & 0.0 & & & & 0.0 & 244.5 & & & & 244.5 \\
\hline 69 & AF8 & Other receivables/payables & -0.5 & & & & -0.5 & -156.7 & & & & -156.7 \\
\hline 70 & B103 & $\begin{array}{l}\text { Changes in net worth due to nominal holding } \\
\text { gains and losses }\end{array}$ & 753.5 & & & & 753.5 & $3,410.3$ & & & & $3,410.3$ \\
\hline
\end{tabular}




\section{Table 3.3: SNA Balance Sheets for the U.S. - Stocks and Changes in Assets}

\begin{tabular}{|c|c|c|c|c|c|c|c|c|c|c|c|c|}
\hline \multicolumn{13}{|c|}{ Stocks and Changes in Assets } \\
\hline \multirow[b]{3}{*}{$\stackrel{\Xi}{.}$} & \multirow[b]{3}{*}{ 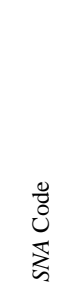 } & & \multirow[b]{3}{*}{ 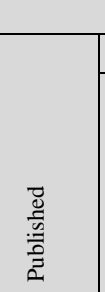 } & \multicolumn{4}{|c|}{ Rest of World } & \multicolumn{5}{|c|}{ Total Economy } \\
\hline & & & & \multicolumn{3}{|c|}{ Adjustments } & \multirow[b]{2}{*}{ 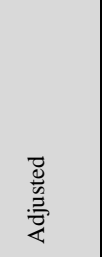 } & \multirow[b]{2}{*}{ 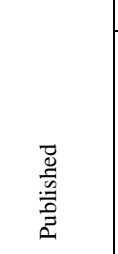 } & \multicolumn{3}{|c|}{ Adjustments } & \multirow[b]{2}{*}{ 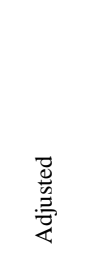 } \\
\hline & & & & 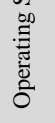 & 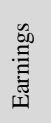 & 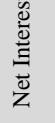 & & & 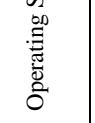 & 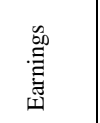 & 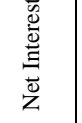 & \\
\hline & & & (1) & $(2)$ & (3) & (4) & (5) & (6) & (7) & (8) & (9) & $(10)$ \\
\hline & & Opening balance sheet & & & & & & & & & & \\
\hline 71 & $\mathrm{AN}$ & Non-financial assets & & & & & & $70,352.4$ & & & & $70,352.4$ \\
\hline 72 & $\mathrm{AF}$ & Financial assets/liabilities & $21,238.9$ & & & & $21,238.9$ & $173,474.4$ & $3,196.0$ & $-3,313.9$ & -136.7 & $173,219.8$ \\
\hline 73 & AF1 & Monetary gold and SDRs & 54.4 & & & & 54.4 & 66.2 & & & & 66.2 \\
\hline 74 & AF2 & Currency and deposits & $1,418.9$ & & & & $1,418.9$ & $14,694.2$ & & & & $14,694.2$ \\
\hline 75 & AF3 & Debt securities & $9,586.9$ & & & & $9,586.9$ & $27,793.4$ & & & & $27,793.4$ \\
\hline 76 & AF4 & Loans & 845.1 & & & & 845.1 & $24,570.9$ & & & & $24,570.9$ \\
\hline 77 & AF5 & Equity & $8,526.3$ & & & & $8,526.3$ & $46,778.3$ & $3,196.0$ & $-3,313.9$ & -136.7 & $46,523.7$ \\
\hline 78 & AF5 & Investment fund shares & 659.3 & & & & 659.3 & $14,391.5$ & & & & $14,391.5$ \\
\hline 79 & AF6 & Insurance, pension and stand. guar. sch. & 0.0 & & & & 0.0 & $26,914.4$ & & & & $26,914.4$ \\
\hline 80 & AF8 & Other receivables/payables & 148.0 & & & & 148.0 & $18,265.5$ & & & & $18,265.5$ \\
\hline \multirow[t]{2}{*}{81} & B90 & Net worth & & & & & & & & & & \\
\hline & & Total changes in assets/liabilities & & & & & & & & & & \\
\hline 82 & AN & Non-financial assets & & & & & & $4,014.8$ & & & & $4,014.8$ \\
\hline 83 & $\mathrm{AF}$ & Financial assets/liabilities & $1,831.2$ & & & & $1,831.2$ & $9,424.5$ & 255.5 & -273.1 & -8.7 & $9,398.1$ \\
\hline 84 & AF1 & Monetary gold and SDRs & -3.2 & & & & -3.2 & -3.3 & & & & -3.3 \\
\hline 85 & AF2 & Currency and deposits & 100.9 & & & & 100.9 & 901.8 & & & & 901.8 \\
\hline 86 & AF3 & Debt securities & 586.9 & & & & 586.9 & 776.1 & & & & 776.1 \\
\hline 87 & AF4 & Loans & 136.7 & & & & 136.7 & 924.8 & & & & 924.8 \\
\hline 88 & AF5 & Equity & 939.9 & & & & 939.9 & $4,111.8$ & 255.5 & -273.1 & -8.7 & $4,085.4$ \\
\hline 89 & AF5 & Investment fund shares & 57.7 & & & & 57.7 & 766.5 & & & & 766.5 \\
\hline 90 & AF6 & Insurance, pension and stand. guar. sch. & 0.0 & & & & 0.0 & 834.7 & & & & 834.7 \\
\hline 91 & AF8 & Other receivables/payables & 12.3 & & & & 12.3 & $1,112.1$ & & & & $1,112.1$ \\
\hline 92 & $\mathrm{~B} 10$ & Changes in net worth & & & & & & & & & & \\
\hline 93 & B101 & Saving and capital transfers & & & & & & & & & & \\
\hline 94 & B102 & Other changes in the volume of assets & & & & & & & & & & \\
\hline \multirow[t]{2}{*}{95} & B103 & Nominal holding gains and losses & & & & & & & & & & \\
\hline & & Closing balance sheet & & & & & & & & & & \\
\hline 96 & AN & Non-financial assets & & & & & & $74,367.2$ & & & & $74,367.2$ \\
\hline 97 & $\mathrm{AF}$ & Financial assets/liabilities & $23,070.1$ & & & & $23,070.1$ & $182,898.9$ & $3,451.5$ & $-3,587.0$ & -145.4 & $182,618.0$ \\
\hline 98 & AF1 & Monetary gold and SDRs & 51.2 & & & & 51.2 & 62.9 & & & & 62.9 \\
\hline 99 & AF2 & Currency and deposits & $1,519.8$ & & & & $1,519.8$ & $15,596.0$ & & & & $15,596.0$ \\
\hline 100 & AF3 & Debt securities & $10,173.8$ & & & & $10,173.8$ & $28,569.5$ & & & & $28,569.5$ \\
\hline 101 & AF4 & Loans & 981.8 & & & & 981.8 & $25,495.7$ & & & & $25,495.7$ \\
\hline 102 & AF5 & Equity & $9,466.2$ & & & & $9,466.2$ & $50,890.1$ & $3,451.5$ & $-3,587.0$ & -145.4 & $50,609.2$ \\
\hline 103 & AF5 & Investment fund shares & 717.0 & & & & 717.0 & $15,158.0$ & & & & $15,158.0$ \\
\hline 104 & AF6 & Insurance, pension and stand. guar. sch. & 0.0 & & & & 0.0 & $27,749.1$ & & & & $27,749.1$ \\
\hline 105 & AF8 & Other receivables/payables & 160.3 & & & & 160.3 & $19,377.6$ & & & & $19,377.6$ \\
\hline 106 & B90 & Net worth & & & & & & & & & & \\
\hline
\end{tabular}




\section{Table 3.3: SNA Balance Sheets for the U.S. - Stocks and Changes in Liabilities and Net Worth}

\begin{tabular}{|c|c|c|c|c|c|c|c|c|c|c|c|c|}
\hline \multicolumn{13}{|c|}{ Stocks and Changes in Liabilities and Net Worth } \\
\hline \multirow[b]{3}{*}{$\stackrel{\mathscr{G}}{.}$} & \multirow[b]{3}{*}{ 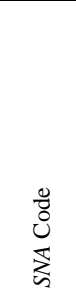 } & & \multirow[b]{3}{*}{ 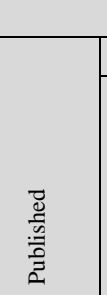 } & \multicolumn{4}{|c|}{ Rest of World } & \multicolumn{5}{|c|}{ Total Economy } \\
\hline & & & & \multicolumn{3}{|c|}{ Adjustments } & \multirow[b]{2}{*}{ 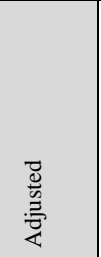 } & \multirow[b]{2}{*}{ 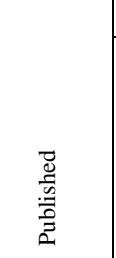 } & \multicolumn{3}{|c|}{ Adjustments } & \multirow[b]{2}{*}{ 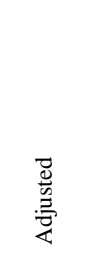 } \\
\hline & & & & 芯 & 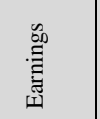 & 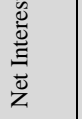 & & & 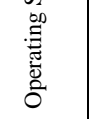 & 泀 & 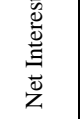 & \\
\hline & & & (1) & (2) & (3) & (4) & (5) & (6) & (7) & (8) & (9) & (10) \\
\hline & & Opening balance sheet & & & & & & & & & & \\
\hline 71 & $\mathrm{AN}$ & Non-financial assets & & & & & & & & & & \\
\hline 72 & $\mathrm{AF}$ & Financial assets/liabilities & $16,717.5$ & $3,196.0$ & $-3,313.9$ & -136.7 & $16,462.9$ & $161,476.6$ & & & & $161,476.6$ \\
\hline 73 & AF1 & Monetary gold and SDRs & 55.2 & & & & 55.2 & 54.4 & & & & 54.4 \\
\hline 74 & AF2 & Currency and deposits & $1,031.4$ & & & & $1,031.4$ & $15,929.6$ & & & & $15,929.6$ \\
\hline 75 & AF3 & Debt securities & $2,649.5$ & & & & $2,649.5$ & $34,730.8$ & & & & $34,730.8$ \\
\hline 76 & AF4 & Loans & $1,000.8$ & & & & $1,000.8$ & $24,737.1$ & & & & $24,737.1$ \\
\hline 77 & AF5 & Equity & $11,927.2$ & $3,196.0$ & $-3,313.9$ & -136.7 & $11,672.6$ & $34,208.8$ & & & & $34,208.8$ \\
\hline 78 & AF5 & Investment fund shares & 0.0 & & & & 0.0 & $15,050.8$ & & & & $15,050.8$ \\
\hline 79 & AF6 & Insurance, pension and stand. guar. sch. & 0.0 & & & & 0.0 & $26,914.3$ & & & & $26,914.3$ \\
\hline 80 & AF8 & Other receivables/payables & 53.4 & & & & 53.4 & $9,850.8$ & & & & $9,850.8$ \\
\hline \multirow[t]{2}{*}{81} & B90 & Net worth & $4,521.4$ & $-3,196.0$ & $3,313.9$ & 136.7 & $4,776.0$ & $82,350.2$ & $3,196.0$ & $-3,313.9$ & -136.7 & $82,095.6$ \\
\hline & & Total changes in assets/liabilities & & & & & & & & & & \\
\hline 82 & $\mathrm{AN}$ & Non-financial assets & & & & & & & & & & \\
\hline 83 & $\mathrm{AF}$ & Financial assets/liabilities & 743.5 & 255.5 & -273.1 & -8.7 & 717.1 & $9,081.7$ & & & & $9,081.7$ \\
\hline 84 & AF1 & Monetary gold and SDRs & -3.3 & & & & -3.3 & -3.2 & & & & -3.2 \\
\hline 85 & AF2 & Currency and deposits & -135.5 & & & & -135.5 & 924.8 & & & & 924.8 \\
\hline 86 & AF3 & Debt securities & 217.4 & & & & 217.4 & $1,145.9$ & & & & $1,145.9$ \\
\hline 87 & AF4 & Loans & 49.1 & & & & 49.1 & 907.2 & & & & 907.2 \\
\hline 88 & AF5 & Equity & 622.2 & 255.5 & -273.1 & -8.7 & 595.8 & $3,508.3$ & & & & $3,508.3$ \\
\hline 89 & AF5 & Investment fund shares & 0.0 & & & & 0.0 & 824.4 & & & & 824.4 \\
\hline 90 & AF6 & Insurance, pension and stand. guar. sch. & 0.0 & & & & 0.0 & 834.7 & & & & 834.7 \\
\hline 91 & AF8 & Other receivables/payables & -6.4 & & & & -6.4 & 939.6 & & & & 939.6 \\
\hline 92 & B10 & Changes in net worth & $1,087.7$ & -255.5 & 273.1 & 8.7 & $1,114.1$ & $4,357.6$ & 255.5 & -273.1 & -8.7 & $4,331.2$ \\
\hline 93 & B101 & Saving and capital transfers & 384.4 & -255.5 & 273.1 & 8.7 & 410.8 & 608.3 & 255.5 & -273.1 & -8.7 & 581.9 \\
\hline 94 & B102 & Other changes in the volume of assets & -50.2 & & & & -50.2 & 339.6 & & & & 339.6 \\
\hline \multirow[t]{2}{*}{95} & B103 & Nominal holding gains and losses & 753.5 & & & & 753.5 & $3,410.3$ & & & & $3,410.3$ \\
\hline & & Closing balance sheet & & & & & & & & & & \\
\hline 96 & AN & Non-financial assets & & & & & & & & & & \\
\hline 97 & $\mathrm{AF}$ & Financial assets/liabilities & $17,461.0$ & $3,451.5$ & $-3,587.0$ & -145.4 & $17,180.1$ & $170,558.3$ & & & & $170,558.3$ \\
\hline 98 & AF1 & Monetary gold and SDRs & 51.9 & & & & 51.9 & 51.2 & & & & 51.2 \\
\hline 99 & AF2 & Currency and deposits & 895.9 & & & & 895.9 & $16,854.4$ & & & & $16,854.4$ \\
\hline 100 & AF3 & Debt securities & $2,866.9$ & & & & $2,866.9$ & $35,876.7$ & & & & $35,876.7$ \\
\hline 101 & AF4 & Loans & $1,049.9$ & & & & $1,049.9$ & $25,644.3$ & & & & $25,644.3$ \\
\hline 102 & AF5 & Equity & $12,549.4$ & $3,451.5$ & $-3,587.0$ & -145.4 & $12,268.5$ & $37,717.1$ & & & & $37,717.1$ \\
\hline 103 & AF5 & Investment fund shares & 0.0 & & & & 0.0 & $15,875.2$ & & & & $15,875.2$ \\
\hline 104 & AF6 & Insurance, pension and stand. guar. sch. & 0.0 & & & & 0.0 & $27,749.0$ & & & & $27,749.0$ \\
\hline 105 & AF8 & Other receivables/payables & 47.0 & & & & 47.0 & $10,790.4$ & & & & $10,790.4$ \\
\hline 106 & B90 & Net worth & $5,609.1$ & $-3,451.5$ & $3,587.0$ & 145.4 & $5,890.0$ & $86,707.8$ & $3,451.5$ & $-3,587.0$ & -145.4 & $86,426.9$ \\
\hline
\end{tabular}




\section{Figure 1: Overview of the SNA and BPM Frameworks}

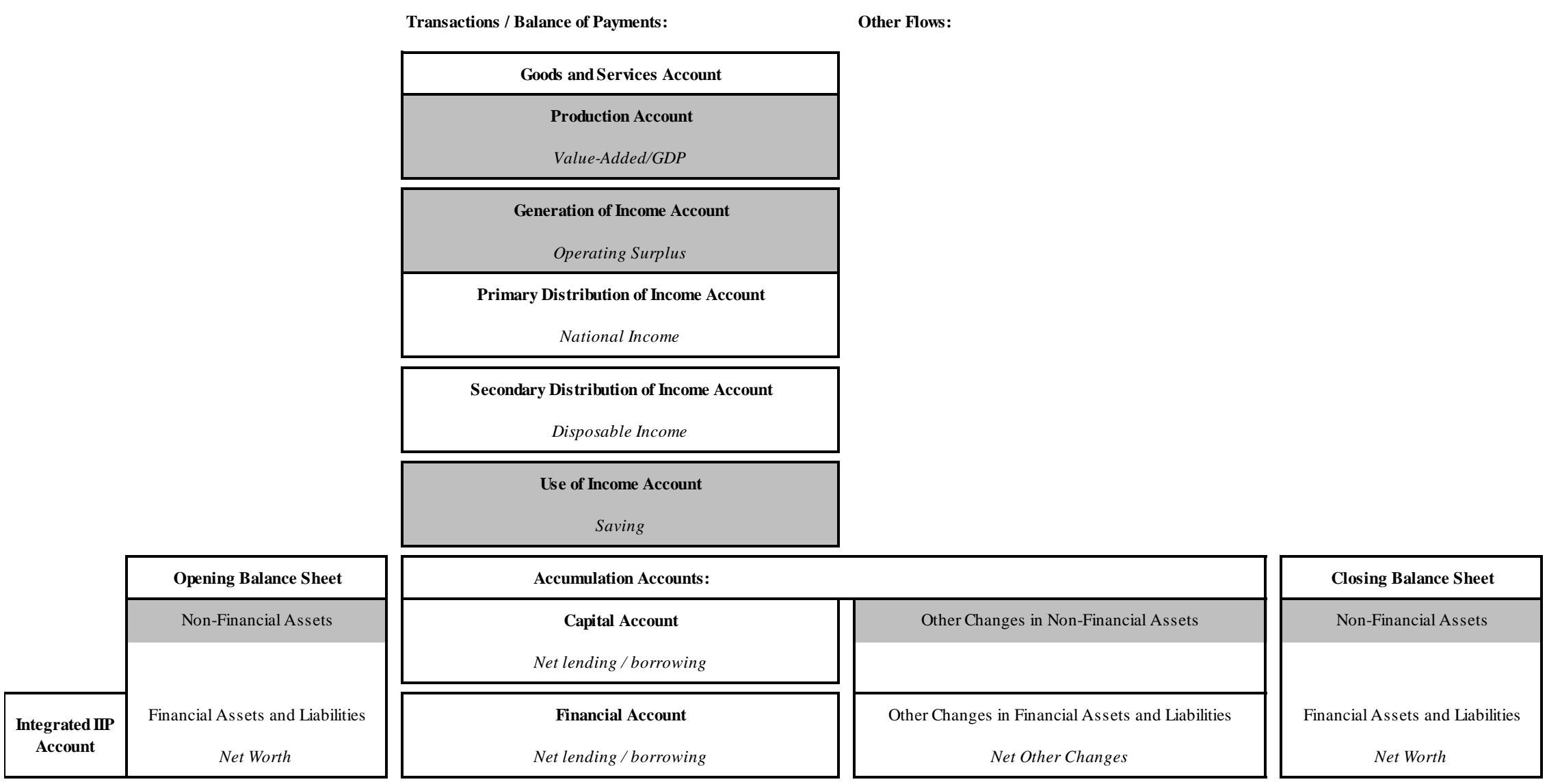

Note: The figure is adapted from BPM, sixth edition, figure 2.1. Account names are shown in bold, and SNA balancing items are shown in italics. Shaded areas do not appear in the BPM framework. 
Figure 2: U.S. Labor Share of Income for 1975 and 2014

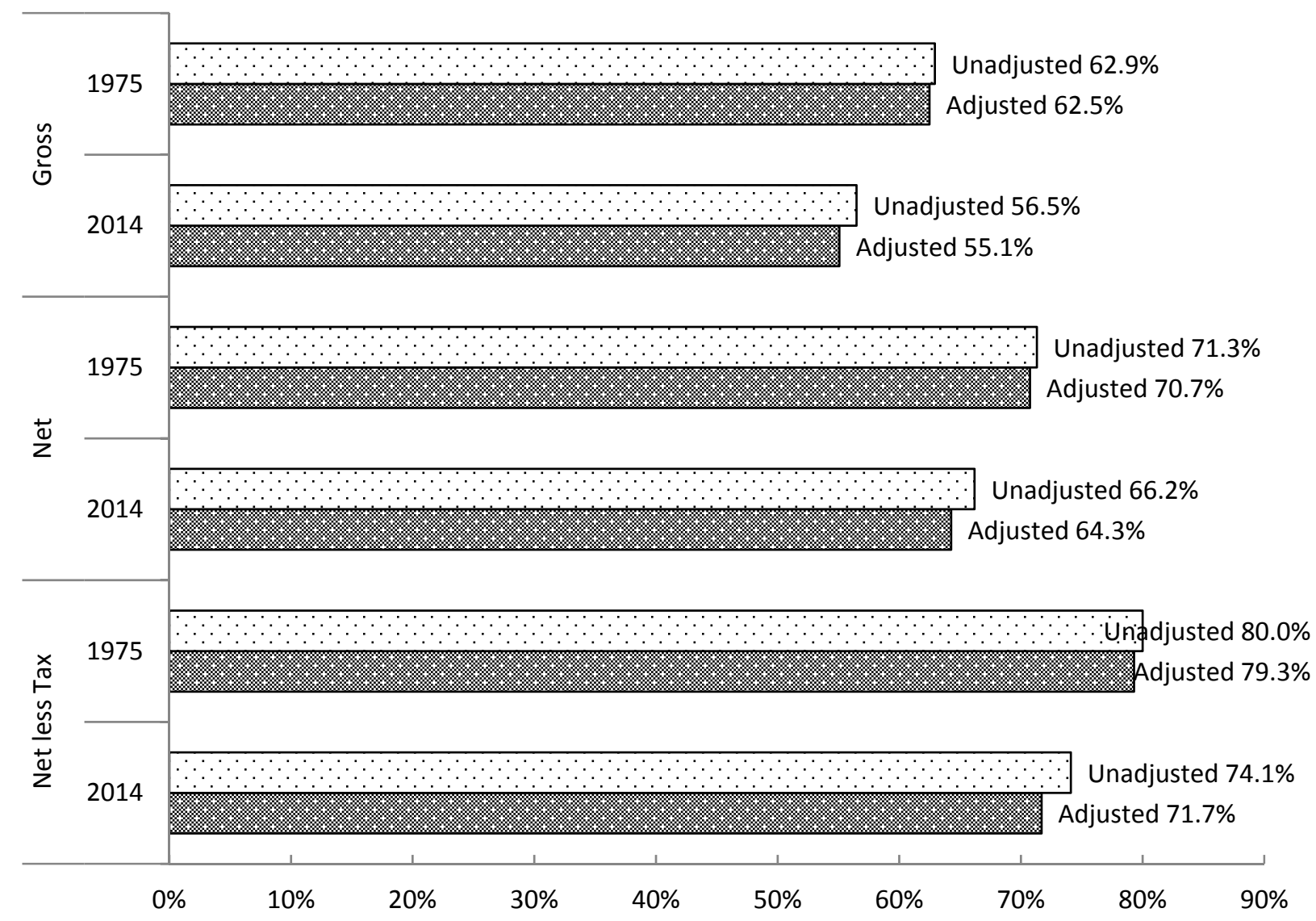

Note: Shares are calculated as a percentage of value-added for corporate business. Gross refers to gross value-added in the denominator, net refers to net value-added in the denominator, and net less tax refers to net value-added minus taxes less subsidies on production and imports in the denominator. See appendix A for a description of calculations. 
Figure 3: U.S. National Saving Rates for 2014

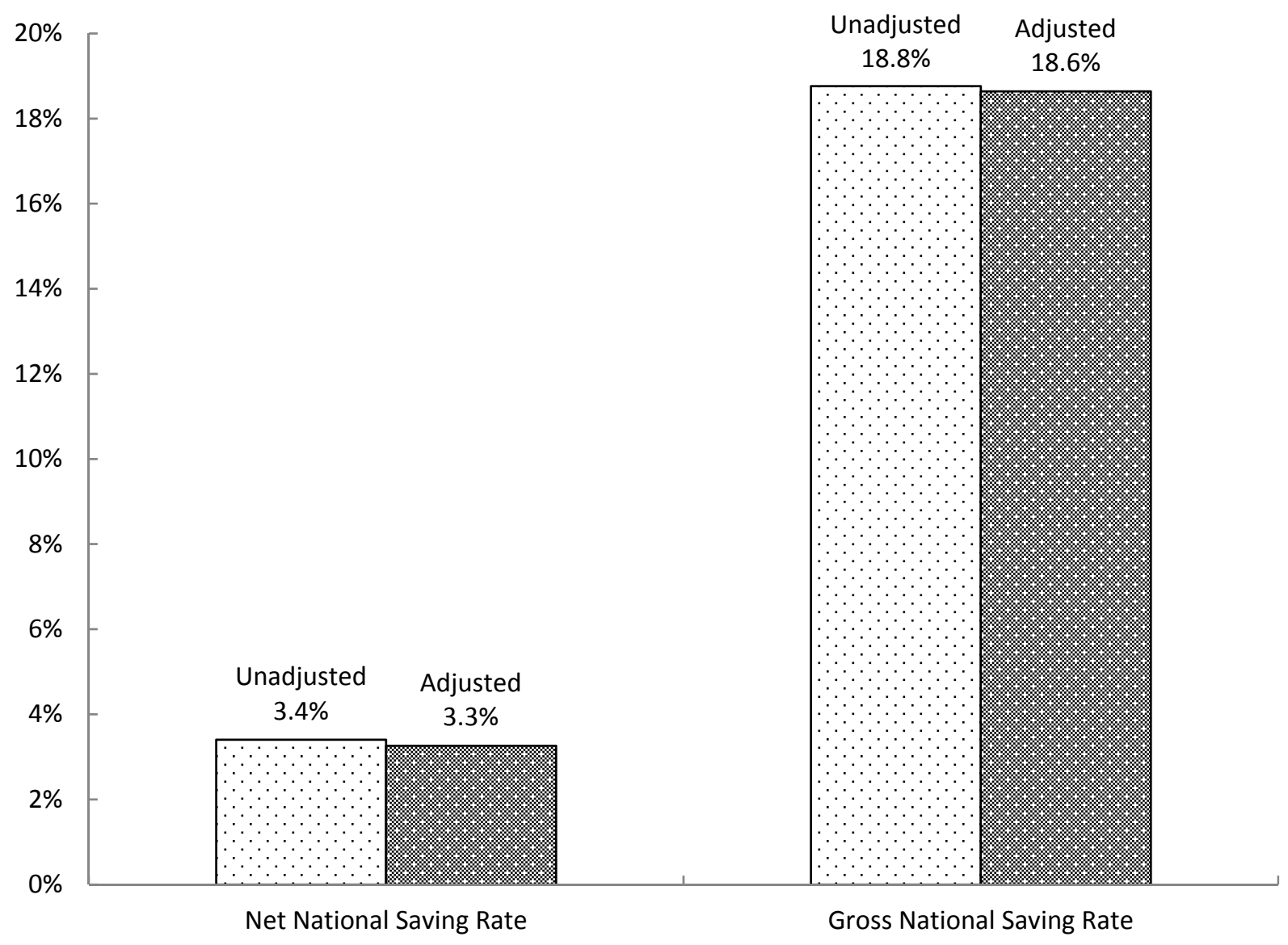

Note: Saving rates are calculated as a percentage of GNI. See appendix A for a description of calculations. 
Figure 4: Return on U.S. Domestic Non-Financial Business for 2014

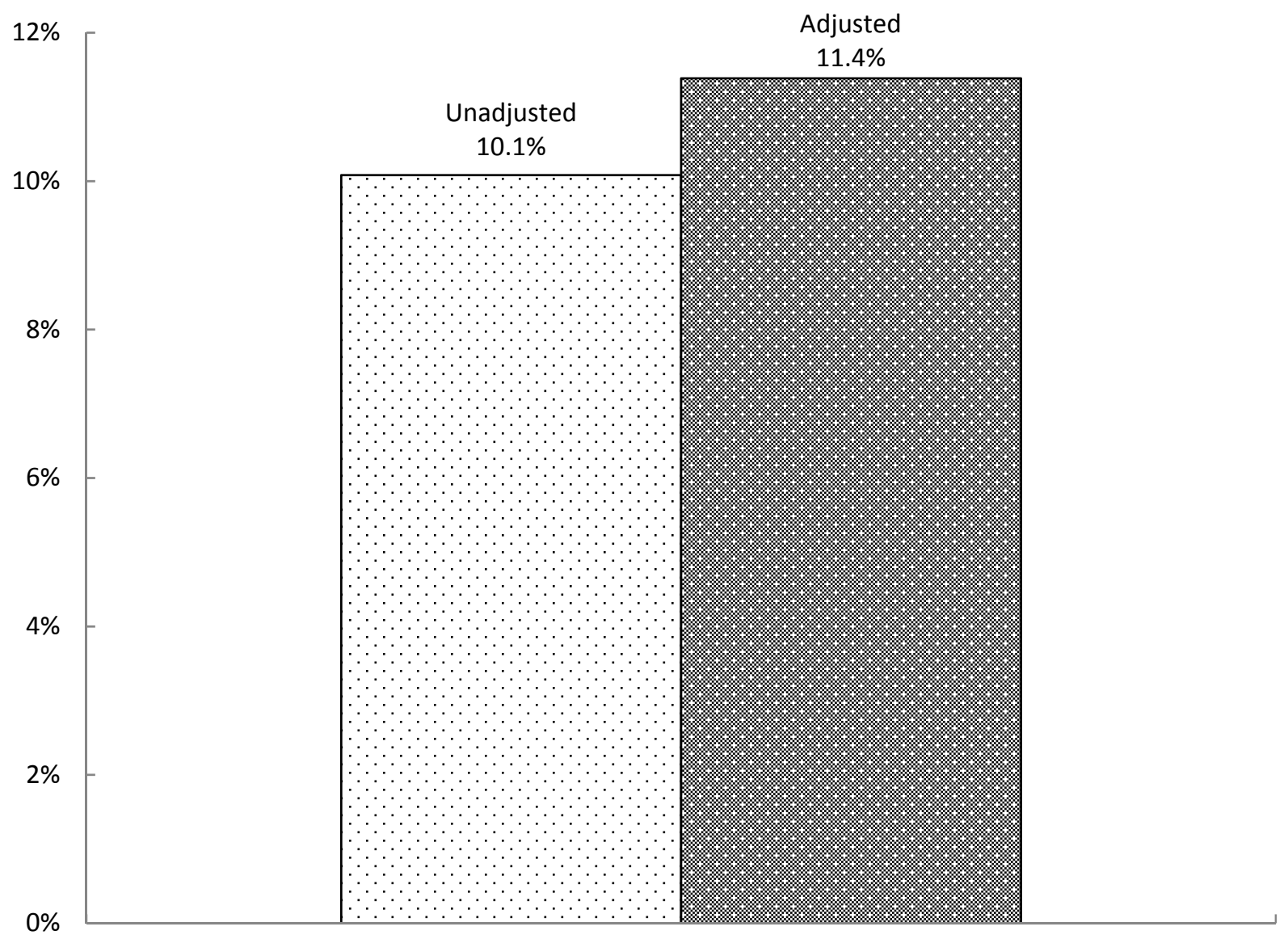

Note: Returns are calculated by dividing net operating surplus by the net stock of produced assets. See appendix A for a description of calculations. 
Figure 5: Return on U.S. Direct Investment Abroad for 2014

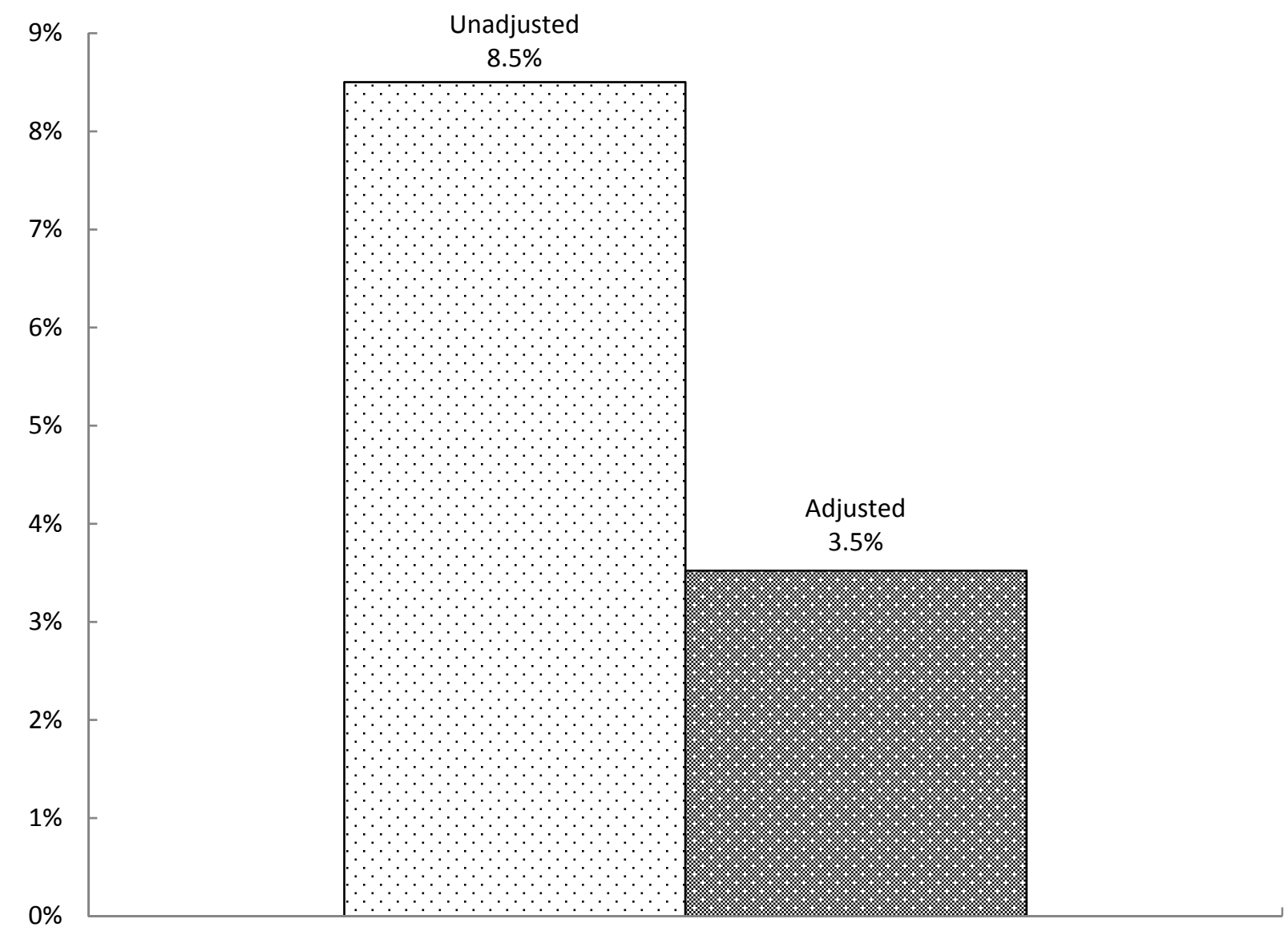

Note: Returns are calculated by dividing direct investment income at current cost by the average of beginning and ending direct investment asset positions at current cost. See appendix A for a description of calculations. 
Figure 6: U.S. External Balances for 2014

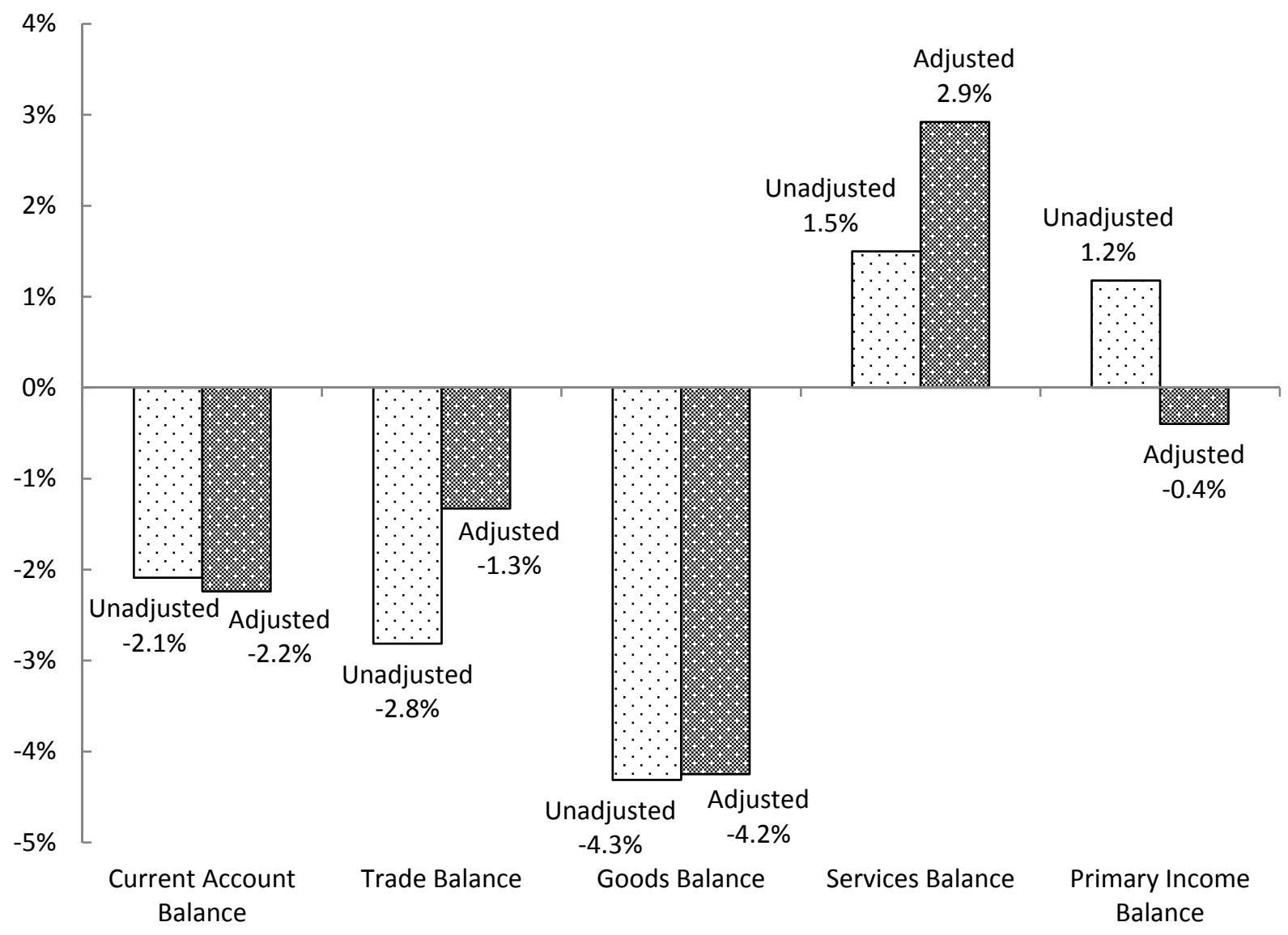

Note: Trade balances are shown as a percentage of expenditure-based GDP. Current account and primary income balances are shown as a percentage of GNI. See appendix A for a description of calculations. 


\section{Appendix Table A1: BPM Direct Investment Position Reconciliation for the U.S.}

\begin{tabular}{|c|c|c|c|c|c|c|c|c|c|c|c|c|c|}
\hline \multicolumn{7}{|c|}{ Assets } & \multirow[b]{2}{*}{ 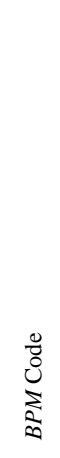 } & \multirow[b]{2}{*}{$\begin{array}{l}\tilde{D} \\
\dot{0} \\
\sum_{\infty}\end{array}$} & & \multicolumn{4}{|l|}{ Liabilities } \\
\hline & & 节 & 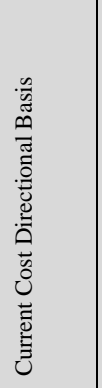 & 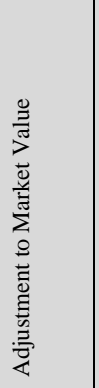 & 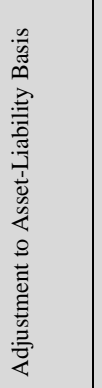 & 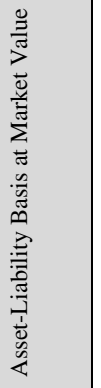 & & & & 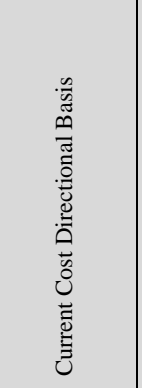 & 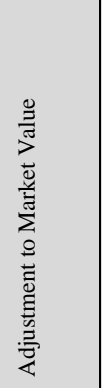 & 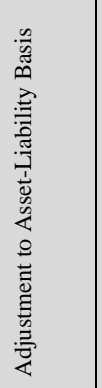 & 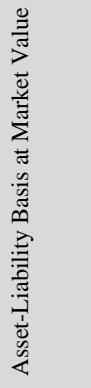 \\
\hline \multirow{13}{*}{ 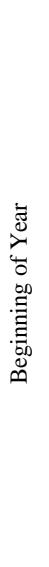 } & \multirow{5}{*}{ 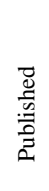 } & & (1) & (2) & (3) & (4) & & & & (5) & (6) & (7) & (8) \\
\hline & & 1 & & & & & & & Net position & $1,975.5$ & -669.8 & & $1,305.8$ \\
\hline & & 2 & $5,296.4$ & 957.8 & 866.5 & $7,120.7$ & 1 & AFD & Direct investment & $3,320.9$ & $1,627.6$ & 866.5 & $5,814.9$ \\
\hline & & 3 & $5,096.4$ & 957.8 & & $6,054.2$ & 1.1 & AF5D & Equity & $2,815.7$ & $1,627.6$ & & $4,443.2$ \\
\hline & & 4 & 199.9 & & 866.5 & $1,066.5$ & 1.2 & AF3D & Debt instruments & 505.2 & & 866.5 & $1,371.7$ \\
\hline & \multirow{4}{*}{ 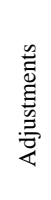 } & 5 & & & & & & & Net position & -263.6 & & & -263.6 \\
\hline & & 6 & -263.6 & & & -263.6 & 1 & AFD & Direct investment & & & & \\
\hline & & 7 & -263.6 & & & -263.6 & 1.1 & AF5D & Equity & & & & \\
\hline & & 8 & & & & & 1.2 & AF3D & Debt instruments & & & & \\
\hline & \multirow{4}{*}{ 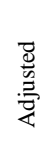 } & 9 & & & & & & & Net position & $1,711.9$ & -669.8 & & $1,042.1$ \\
\hline & & 10 & $5,032.8$ & 957.8 & 866.5 & $6,857.1$ & 1 & AFD & Direct investment & $3,320.9$ & $1,627.6$ & 866.5 & $5,814.9$ \\
\hline & & 11 & $4,832.8$ & 957.8 & & $5,790.6$ & 1.1 & AF5D & Equity & $2,815.7$ & $1,627.6$ & & $4,443.2$ \\
\hline & & 12 & 199.9 & & 866.5 & $1,066.5$ & 1.2 & AF3D & Debt instruments & 505.2 & & 866.5 & $1,371.7$ \\
\hline \multirow{12}{*}{ 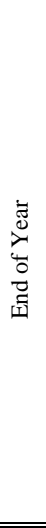 } & \multirow{4}{*}{ 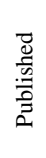 } & 13 & & & & & & & Net position & $2,092.5$ & $-1,272.6$ & & 819.9 \\
\hline & & 14 & $5,633.1$ & 643.7 & 912.6 & $7,189.4$ & 1 & AFD & Direct investment & $3,540.7$ & $1,916.2$ & 912.6 & $6,369.5$ \\
\hline & & 15 & $5,396.5$ & 643.7 & & $6,040.1$ & 1.1 & AF5D & Equity & $2,979.5$ & $1,916.2$ & & $4,895.8$ \\
\hline & & 16 & 236.7 & & 912.6 & $1,149.3$ & 1.2 & AF3D & Debt instruments & 561.1 & & 912.6 & $1,473.8$ \\
\hline & \multirow{4}{*}{ 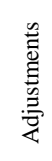 } & 17 & & & & & & & Net position & -290.0 & & & -290.0 \\
\hline & & 18 & -290.0 & & & -290.0 & 1 & AFD & Direct investment & & & & \\
\hline & & 19 & -290.0 & & & -290.0 & 1.1 & AF5D & Equity & & & & \\
\hline & & 20 & & & & & 1.2 & AF3D & Debt instruments & & & & \\
\hline & \multirow{4}{*}{ 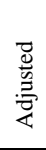 } & 21 & & & & & & & Net position & $1,802.5$ & $-1,272.6$ & & 529.9 \\
\hline & & 22 & $5,343.2$ & 643.7 & 912.6 & $6,899.4$ & 1 & AFD & Direct investment & $3,540.7$ & $1,916.2$ & 912.6 & $6,369.5$ \\
\hline & & 23 & $5,106.5$ & 643.7 & & $5,750.2$ & 1.1 & AF5D & Equity & $2,979.5$ & $1,916.2$ & & $4,895.8$ \\
\hline & & 24 & 236.7 & & 912.6 & $1,149.3$ & 1.2 & AF3D & Debt instruments & 561.1 & & 912.6 & $1,473.8$ \\
\hline
\end{tabular}

Note: BEA presents direct investment statistics on two bases: the directional basis and the asset-liability basis. On a directional basis, direct investment claims and liabilities are classified according to whether the direct investor is a U.S. resident or a foreign resident. On this basis, U.S. direct investment abroad is the net claims of a U.S. parent on its foreign affiliates. On the asset-liability basis, direct investment claims and liabilities are classified according to whether the direct investment enterprise that receives the funds is resident in the U.S. or abroad. A direct investment asset is created when a U.S. parent or a U.S. affiliate establishes a claim on a related foreign person. Similarly, a direct investment liability is established when a foreign person establishes a claim on a related direct investment enterprise in the United States. Furthermore, BEA publishes direct investment statistics based on three valuation methods: historical cost, current cost, and market value. Historical cost is the basis on which BEA's direct investment surveys collect direct investment position data because that is the primary valuation method used in company accounting records. Current cost estimates revalue parents' historical cost equity claims in their affiliates' plant and equipment, land, and inventory stocks to a replacement value of tangible assets. The market value estimates are featured in BEA's international investment position accounts because market valuation is used for other functional categories in these accounts. 


\section{Appendix A: Calculations for Analytic Uses}

This appendix provides details on calculations for each of the five analytic uses of the U.S. economic accounts presented in section 5.3.

\section{Labor Share of Income}

Calculations are based on data from NIPA tables 1.14 and 7.5 for corporate business. We calculate the 2014 unadjusted gross labor share by dividing compensation by gross value-added (GVA) as follows:

$$
\text { Unadjusted Gross Labor Share }=\frac{\text { Compensation }}{G V A}=\frac{5,647.8}{10,000.2}=56.5 \% \text {. }
$$

Gross value-added is the sum of compensation, taxes less subsidies on production and imports, net operating surplus, and consumption of fixed capital. We calculate the 2014 unadjusted net labor share by dividing compensation by net value-added (NVA) as follows:

$$
\text { Unadjusted Net Labor Share }=\frac{\text { Compensation }}{\text { NVA }}=\frac{5,647.8}{8,534.5}=66.2 \% \text {. }
$$

Net value-added excludes consumption of fixed capital. We calculate the 2014 unadjusted net labor share less taxes by dividing compensation by net value-added minus taxes less subsidies on production and imports minus current business transfer payments (NVAT) as follows:

$$
\text { Unadjusted Net Labor Share less Taxes }=\frac{\text { Compensation }}{\text { NVAT }}=\frac{5,647.8}{7,622.8}=74.1 \% \text {. }
$$

We calculate the adjusted shares by adding the $\$ 255.5$ billion adjustment for operating surplus (OS) to the denominator in each calculation as follows:

$$
\begin{aligned}
& \text { Adjusted Gross Labor Share }=\frac{\text { Compensation }}{\text { GVA+OS Adjustment }}=\frac{5,647.8}{10,000.2+255.5}=55.1 \%, \\
& \text { Adjusted Net Labor Share }=\frac{\text { Compensation }}{\text { NVA+OS Adjustment }}=\frac{5,647.8}{8,534.5+255.5}=64.3 \%,
\end{aligned}
$$
and

$$
\text { Adjusted Net Labor Share less Taxes }=\frac{\text { Compensation }}{\text { NVAT+OS Adjustment }}=\frac{5,647.8}{7,622.8+255.5}=71.7 \% \text {. (A6 }
$$

We calculate the 1975 shares in the same manner. Capital shares of income can also be calculated and would be equal to one minus the labor share.

\section{National Saving Rates}

Calculations are based on data from table 3.1. We calculate the 2014 unadjusted net national saving rate by dividing net national saving (line 34) by GNI (line 22) as follows:

$$
\text { Unadjusted Net Rate }=\frac{\text { Net National } \text { Saving }}{\text { GNI }}=\frac{608.7}{17,892.1}=3.4 \% \text {. }
$$


We calculate the unadjusted gross national saving rate by dividing gross national saving (line 32) by GNI (line 22) as follows:

$$
\text { Unadjusted Gross Rate }=\frac{\text { Gross National Saving }}{\text { GNI }}=\frac{3,356.7}{17,892.1}=18.8 \% .
$$

We calculate the adjusted rates by substituting the adjusted measures from table 3.1 as follows:

$$
\text { Adjusted Net Rate }=\frac{\text { Adjusted Net National Saving }}{\text { Adjusted GNI }}=\frac{582.3}{17,865.7}=3.3 \%
$$

and

$$
\text { Adjusted Gross Rate }=\frac{\text { Adjusted Gross National Saving }}{\text { Adjusted GNI }}=\frac{3,330.3}{17,865.7}=18.6 \% \text {. }
$$

$\underline{\text { Return on U.S. Domestic Non-Financial Business }}$

Calculations are based on data from Osborne and Retus (2017). We calculate the 2014 unadjusted return by dividing net operating surplus (NOS) for non-financial business available in the U.S. NIPAs by the net stock of produced assets for non-financial business available in the U.S. Fixed Assets Accounts as follows:

$$
\text { Unadjusted Return }=\frac{\text { Nos }}{\text { Net Stock of Produced Assets }}=\frac{1,680.4}{16,670.4}=10.1 \% \text {. }
$$

We calculate the adjusted return by adding the adjustment of $\$ 255.5$ billion (less $\$ 38.1 .0$ billion for financial industries) on operating surplus (OS) for non-financial industries to the numerator as follows:

$$
\text { Adjusted Return }=\frac{\text { NoS }+ \text { OS Adjustment }}{\text { Net Stock of Produced Assets }}=\frac{1,680.4+255.5-38.1}{16,670.4}=11.4 \% \text {. }
$$

The denominator includes capital measures of intellectual property products, which we do not adjust as explained in section 5.2.

\section{$\underline{\text { Return on U.S. Direct Investment Abroad }}$}

Calculations are based on data from table 1.1 and appendix table A1. We calculate the 2014 unadjusted return by dividing income on USDIA at current cost presented in table 1.1 (line 22) by the average of beginning and ending direct investment asset positions at current cost presented in appendix table A1 (lines 2 and 14) as follows:

$$
\text { Unadj. Return }=\frac{\text { Unadjusted Income on USDIA }}{(\text { Unadj. Beg. Assets }+ \text { Unadj. End. Assets }) \div 2}=\frac{464.6}{(5,296.4+5,633.1) \div 2}=8.5 \% \text {. }
$$

We calculate the adjusted return using the income on USDIA reported in table 1.1 (line 22) and the adjusted beginning and ending direct investment asset positions reported in appendix table A1 (lines 10 and 22) as follows: 


$$
\text { Adj. Return }=\frac{\text { Adjusted Income on USDIA }}{(\text { Adj. Beg. Assets }+ \text { Adj. End. Assets }) \div 2}=\frac{182.7}{(5,032.8+5,343.2) \div 2}=3.5 \% \text {. }
$$

\section{$\underline{\text { U.S. External Balances }}$}

Calculations are based on data from tables 1.1 and 3.1. We calculate the 2014 unadjusted balances from table 1.1 as a percentage of unadjusted expenditure-based GDP or GNI from table 3.1 as follows:

$$
\begin{aligned}
& \text { Unadjusted Current Account }=\frac{\text { Unadjusted CA Balance }}{\text { Unadjusted } G N I}=\frac{-373.8}{17,892.1}=-2.1 \%, \\
& \text { Unadjusted Trade }=\frac{\text { Unadjusted Trade Balance }}{\text { Unadjusted GDP }}=\frac{-490.3}{17,427.6}=-2.8 \%, \\
& \text { Unadjusted Goods }=\frac{\text { Unadjusted Goods Balance }}{\text { Unadjusted GDP }}=\frac{-751.5}{17,427.6}=-4.3 \%, \\
& \text { Unadjusted Services }=\frac{\text { Unadjusted Services Balance }}{\text { Unadjusted GDP }}=\frac{261.2}{17,427.6}=1.5 \%,
\end{aligned}
$$

and

$$
\text { Unadjusted Primary Income }=\frac{\text { Unadjusted Primary Income Balance }}{\text { Unadjusted GNI }}=\frac{210.8}{17,892.1}=1.2 \% \text {. }
$$

We calculate the adjusted balances from table 1.1 as a percentage of adjusted expenditure-based GDP or GNI from table 3.1 as follows:

$$
\begin{aligned}
& \text { Adjusted Current Account }=\frac{\text { Adjusted CA Balance }}{\text { Adjusted GNI }}=\frac{-400.2}{17,865.7}=-2.2 \%, \\
& \text { Adjusted Trade }=\frac{\text { Adjusted Trade Balance }}{\text { Adjusted GDP }}=\frac{-234.9}{17,683.1}=-1.3 \%, \\
& \text { Adjusted Goods }=\frac{\text { Adjusted Goods Balance }}{\text { Adjusted GDP }}=\frac{-751.5}{17,683.1}=-4.2 \%, \\
& \text { Adjusted Services }=\frac{\text { Adjusted Services Balance }}{\text { Adjusted GDP }}=\frac{516.6}{17,683.1}=2.9 \%,
\end{aligned}
$$

and

$$
\text { Adjusted Primary Income }=\frac{\text { Adjusted Primary Income Balance }}{\text { Adjusted GNI }}=\frac{-71.1}{17,865.7}=-0.4 \% \text {. }
$$

